\title{
Diseases of glycosylation beyond classical congenital disorders of glycosylation
}

\author{
Hennet, Thierry
}

\begin{abstract}
BACKGROUND: Diseases of glycosylation are rare inherited disorders, which are often referred to as congenital disorders of glycosylation (CDG). Several types of CDG have been described in the last decades, encompassing defects of nucleotide-sugar biosynthesis, nucleotide-sugar transporters, glycosyltransferases and vesicular transport. Although clinically heterogeneous, most types of CDG are associated with neurological impairments ranging from severe psychomotor retardation to moderate intellectual disabilities. CDG are mainly caused by defects of N-glycosylation, owing to the simple detection of under-glycosylated serum transferrin by isoelectric focusing. SCOPE OF REVIEW: In the last years, several disorders of O-glycosylation, glycolipid and glycosaminoglycan biosynthesis have been described, which are known by trivial names not directly associated with the family of CDG. The present review outlines 64 gene defects affecting glycan biosynthesis and modifications, thereby underlining the complexity of glycosylation pathways and pointing to unexpected phenotypes and functional redundancies in the control of glycoconjugate biosynthesis. MAJOR CONCLUSIONS: The increasing application of whole-genome sequencing techniques unravels new defects of glycosylation, which are associated to moderate forms of mental disabilities. GENERAL SIGNIFICANCE: The knowledge gathered through the investigation of CDG increases the understanding of the functions associated to protein glycosylation in humans. This article is part of a Special Issue entitled Glycoproteomics.
\end{abstract}

DOI: https://doi.org/10.1016/j.bbagen.2012.02.001

Posted at the Zurich Open Repository and Archive, University of Zurich

ZORA URL: https://doi.org/10.5167/uzh-74134

Journal Article

Accepted Version

Originally published at:

Hennet, Thierry (2012). Diseases of glycosylation beyond classical congenital disorders of glycosylation. Biochimica Et Biophysica Acta, 1820(9):1306-1317.

DOI: https://doi.org/10.1016/j.bbagen.2012.02.001 


\title{
Diseases of glycosylation beyond classical congenital disorders of glycosylation
}

\author{
Thierry Hennet
}

Institute of Physiology and Center for Integrative Human Physiology, University of Zurich, Winterthurerstrasse 190, CH-8057 Switzerland

Address correspondence to:

Thierry Hennet, Institute of Physiology, University of Zürich, Winterthurerstrasse 190, CH-8057 Zürich, Switzerland

Phone: +4144635 5080

Fax: +41 446356814

E-mail: thennet@access.uzh.ch 


\begin{abstract}
BACKGROUND: Diseases of glycosylation are rare inherited disorders, which are often referred to as congenital disorders of glycosylation (CDG). Several types of CDG have been described in the last decades, encompassing defects of nucleotide-sugar biosynthesis, nucleotide-sugar transporters, glycosyltransferases and vesicular transport. Although clinically heterogeneous, most types of CDG are associated with neurological impairments ranging from severe psychomotor retardation to moderate intellectual disabilities. CDG are mainly caused by defects of $\mathrm{N}$-glycosylation, owing to the simple detection of under-glycosylated serum transferrin by isoelectric focusing.

SCOPE OF REVIEW: In the last years, several disorders of O-glycosylation, glycolipid and glycosaminoglycan biosynthesis have been described, which are known by trivial names not directly associated with the family of CDG. The present review outlines 64 gene defects affecting glycan biosynthesis and modifications, thereby underlining the complexity of glycosylation pathways and pointing to unexpected phenotypes and functional redundancies in the control of glycoconjugate biosynthesis.
\end{abstract}

MAJOR CONCLUSIONS: The increasing application of whole-genome sequencing techniques unravels new defects of glycosylation, which are associated to moderate forms of mental disabilities.

GENERAL SIGNIFICANCE: The knowledge gathered through the investigation of CDG increases the understanding of the functions associated to protein glycosylation in humans.

\title{
Highlights
}

- Diseases of glycosylation are classified as congenital disorders of glycosylation.

- CDG are rare inherited diseases with a broad range of clinical manifestation.

- To date 64 gene defects have been identified as cause of CDG.

- Genotype-phenotype comparisons reveal unexpected functional redundancies.

\section{Keywords}

Glycosylation, glycoprotein, glycolipid, glycosyltransferase, disease, mutation 


\section{Historical remarks}

Diseases of glycosylation are rather recent additions to the growing list of known inherited diseases. In fact, most disorders of glycosylation have been described in the last 20 years. These diseases were first called carbohydrate-deficient glycoprotein syndromes $(C D G S)^{1}[1]$, but were renamed congenital disorders of glycosylation (CDG) in 1999 [2] to encompass all types of glycoconjugates. In fact, some gene defects affect multiple glycosylation pathways, hence leading to structural alteration in multiple classes of glycoconjugates. Originally, CDG have been divided into two groups. CDG-I included all disorders of N-glycosylation site occupancy and CDG-II all other disorders of N-glycosylation, Oglycosylation and glycolipid biosynthesis. As the number of glycosylation disorders approached the mark of 50 , nomenclature has been simplified by focusing on the name of the mutated gene followed by the abbreviation CDG [3]. Accordingly, the disorder caused by mutations in the phosphomannomutase-2 gene is referred to as PMM2-CDG.

The initial impetus for the discovery of several diseases of glycosylation was given by the serendipitous identification of CDG cases while applying a blood test aimed at detecting alcohol abuse. In the late seventies, the neurologist Helena Stibler observed the loss of negatively charged serum transferrin in situations of chronic alcohol abuse [4]. Serum transferrin normally carries two Nglycans that are terminated by negatively-charged sialic acid (Sia). The loss of $\mathrm{N}$-glycans on transferrin can easily be monitored by isoelectric focusing using few microliters of blood serum. The pediatrician Jaak Jaeken [5] and Helena Stibler [6] were the first to identify CDG patients using serum transferrin isoelectric focusing. The broad application of this simple test has paved the way to the identification of several defects of $\mathrm{N}$-glycosylation. Unfortunately, similar tests unraveling defects of O-glycosylation or glycolipid glycosylation are not available, mainly because of the structural heterogeneity of O-glycans and of their tissue-specific expression. Accordingly, only few defects of Oglycosylation and glycolipid biosynthesis have been characterized so far. In fact, most of these defects were identified by genetic linkage analysis in large families.

In the last years, advanced sequencing techniques have revealed new gene defects linked to glycosylation disorders. These disorders broaden the range of symptoms and organ involvements associated with CDG. Originally, the study of severe clinical phenotypes led to the discovery of most types of CDG. However, recent developments have shown that medical teams should also consider

\footnotetext{
${ }^{1}$ CDGS, carbohydrate-deficient glycoprotein syndrome; CDG, congenital disorders of glycosylation; Sia, sialic acid; Dol, dolichol; Dol-P-Man, dolichol-phosphate mannose; GPI, glycosylphosphatidylinositol; Man, mannose; LLO, lipid-linked oligosaccharide; OST, oligosaccharyltransferase; ERAD, ER-associated degradation; GAG, glycosaminoglycan; $\mathrm{PNH}$, paroxysmal nocturnal hemoglobinuria
} 
milder symptoms and even additional clinical findings linked to mutations in known genes as the variability of clinical phenotypes will undoubtedly expand. In spite of the rapid progress achieved, the establishment of relationships between CDG phenotypes and specific glycoprotein and glycolipid functions remains a major challenge.

\section{Defects of single and multiple glycoconjugate classes}

The majority of CDG known to date are defects of $\mathrm{N}$-glycosylation, which have been identified using the convenient transferrin isoelectric focusing test. Some of the gene mutations usually described in the context of $\mathrm{N}$-glycosylation also affect other classes of glycosylation. For example, defects of dolichol-phosphate-mannose (Dol-P-Man) biosynthesis lead to alterations of $\mathrm{N}$-glycosylation, $\mathrm{O}$ mannosylation and glycosylphosphatidylinositol (GPI) assembly, because Dol-P-Man is the substrate of glycosyltransferases in these three pathways. Similarly, disorders of nucleotide-sugar transport and alterations of glycosyltransferase localization have consequences on several classes of glycosylation. In the following overview, individual gene defects are arbitrarily grouped according to the main class of glycosylation affected (Table 1 ).

\subsection{Defects of nucleotide-sugar biosynthesis}

\subsubsection{Phosphomannomutase}

Mannose (Man) is a major carbohydrate used in the biosynthesis of N-glycans, O-Man glycans and GPI-anchor. Accordingly, defects in the cytosolic enzymes phosphomannomutase and mannosephosphate isomerase, which catalyze the conversion of Man-6-P to Man-1-P and of fructose-6-P to Man-6-P, respectively (Fig. 1), affect these three classes of glycosylation. Mutations in the phosphomannomutase-2 (PMM2, OMIM ID: 601785) gene represent by far the most frequent type of $C D G$, with an incidence of about 1 to $50^{\prime} 000$. To date, more than 100 mutations in the PMM2 gene have been described [7]. Interestingly, the R141H mutation, which is the most common mutation by far, is found in 1 out of 80 individuals in most human populations [8]. However, homozygosity for the $\mathrm{R} 141 \mathrm{H}$ allele is never found because the $\mathrm{R} 141 \mathrm{H}$ substitution completely abolishes the PMM2 activity, which is essential to complete embryogenesis [9]. PMM2-CDG, which was previously known as CDG-la, is mainly associated with neurologic symptoms like psychomotor retardation, epilepsy, ataxia and visual impairment. Other manifestations such as cardiomyopathy, hypotonia and coagulopathy are also frequently observed [10].

\subsubsection{Mannose-phosphate isomerase}

Whereas PMM2-CDG is mainly associated with neurological features, such a neurological involvement is missing from the clinical picture of mannose-phosphate isomerase (MPI, OMIM ID: 
154550) deficiency, previously called CDG-lb. This difference is surprising considering the proximity of the two enzymatic reactions in Man-1-P biosynthesis (Fig. 1). Most MPI-CDG cases present with diarrhea, vomiting, gastrointestinal bleeding, protein-losing enteropathy, hepatomegaly and hepatic fibrosis [11]. MPI-CDG is one of the two types of CDG that can be treated by dietary monosaccharide supplementation [12].

\subsubsection{Glutamine-fructose-6-phosphate transaminase 1}

Mutations in the gene encoding glutamine-fructose-6-phosphate transaminase 1 (GFPT1, OMIM ID: 138292) have been recently related to a form of congenital myasthenic syndrome mainly characterized by limb-girdle weakness [13]. As many as 18 GFPT1 mutations were found in 13 families of different ethnical background. The GFPT1 enzyme catalyzes a rate-limiting step in the biosynthesis of UDP-N-acetylglucosamine (GICNAC), which is a donor substrate found in all classes of glycosylation, even counting cytoplasmic/nuclear GIcNAc-ylation [14]. UDP-GIcNAc is also a substrate in the biosynthesis of Sia, suggesting that sialylation may also be impaired in GFPT1 deficiency (Fig.

1). Decreased O-GIcNAc-ylation levels were observed in protein extracts isolated from muscle biopsies. The molecular mechanisms underlying the neuromuscular disorder are unknown. Considering the broad involvement of UDP-GIcNAc in glycosylation, it will be extremely difficult to narrow down the glycoproteins or glycolipids involved in the myasthenic phenotypes. Furthermore, intracellular UDP-GIcNAc levels fluctuate according to nutrient availability, hence affecting processes like protein O-GlcNAc-ylation and the branching of N-glycans [15]. These dynamic changes themselves influence multiple signaling pathways [16], thereby complicating even further the analysis of the functional impact of GFPT1 mutations.

\subsubsection{UDP-GICNAc 2-epimerase}

As mentioned above, UDP-GIcNAc is a point of entry for the biosynthesis of Sia (Fig. 1)and the UDPGIcNAc 2-epimerase/N-acetylmannosamine kinase (GNE, OMIM ID: 603824) enzyme is rate-limiting in this pathway [17]. Mutations in the GNE gene are associated with a mild form of a neuromuscular disorder called hereditary inclusion body myopathy [18]. The disease is characterized by a late onset myopathy mostly limited to leg muscles. The examination of muscle biopsies revealed intramuscular vacuoles and filamentous inclusions of unknown origin. Corresponding glycan analysis showed decreased levels of sialylated O-glycans whereas sialylation of N-glycans remained unchanged [19]. The weak phenotype of GNE deficiency raises several questions regarding the importance of Sia salvage pathways in compensating for the loss of endogenous Sia biosynthesis.

\subsubsection{Galactose activation}

Galactosemia, which is caused by mutations in galactokinase (GALK, OMIM ID: 604313), UDP-Gal 4epimerase (GALE, OMIM ID: 606953) and Gal-1-P uridylyltransferase (GALT, OMIM ID: 606999) genes 
(Fig. 1), is sometimes associated with abnormal N-glycosylation [20]. However, most symptoms result from the accumulation of toxic intermediates and by-products such as Gal-1-P and galactitol. Accordingly, galactosemia is usually not considered as a true disease of glycosylation and will not be discussed further in this overview.

\subsection{Defects of dolichol biosynthesis}

Some glycosyltransferase reactions require Dol-P linked donor substrates like Dol-P-Man and Dol-PGlc. In the ER, Dol is also used as carrier for the growing oligosaccharide, which, when completed, is transferred en bloc to specific asparagine residues on nascent glycoproteins. Defects of Dol biosynthesis lead to limited availability of oligosaccharide carriers and hence to decreased $\mathrm{N}$ glycosylation. To date, three defects of Dol biosynthesis have been characterized.

\subsubsection{Dehydrodolichyl diphosphate synthase}

Dehydrodolichyl diphosphate synthase (DHDDS, OMIM ID: 608172) is the enzyme elongating polyprenol to dehydrodolichol. The human DHDDS enzyme shares similarity to prokaryotic cis-prenyl synthases involved in undecaprenol biosynthesis. A mutation in the DHDDS gene, which introduces the substitution $\mathrm{K} 42 \mathrm{E}$, has been recently identified in a group of Ashkenazi Jewish patients affected of retinitis pigmentosa $[21,22]$. These patients did not present any additional symptoms. The levels of polyprenol and the status of protein glycosylation have not been examined in DHDDS-deficient cells, so it is at this stage unclear whether the mutation has any impact on glycosylation.

\subsubsection{Steroid 5- $\alpha$-reductase-3}

The next gene associated with decreased Dol biosynthesis is steroid 5- $\alpha$-reductase-3 (SRD5A3, OMIM ID: 611715), which encodes the polyprenol reductase enzyme [23]. Five SRD5A3 mutations have been reported so far in patients of Arabian, Turkish and Polish background. These mutations encompass the rearrangement 286deICAAinsTGAGTAAGGC and the nonsense mutations W107X, S10X, R142X and Y163X. These mutations lead to truncated forms of the SRD5A3 protein, suggesting that the enzymatic activity was either totally lost or strongly compromised. Despite the putative loss of polyprenol reductase activity, substantial amounts of Dol-P linked oligosaccharides were observed, thus suggesting alternate biosynthesis pathways. The patients presented with severe symptoms like mental retardation, congenital heart defects and eye anomalies, ichthyosiform dermatitis and endocrine disorders $[23,24]$.

\subsubsection{Dolichol kinase}

Dol undergoes phosphorylation before entering glycosylation pathways. This phosphorylation is catalyzed by a dedicated kinase encoded by the TMEM15 gene (OMIM ID: 610746). To date, four patients harboring TMEM15 mutations a have been described. The patients presented severe 
symptoms like pronounced failure to thrive, ichthyosis, hypotonia, seizures, hypoglycaemia and died in early childhood [25].

Whereas glycosylation was not investigated during the characterization of the DHDDS cases, the SRD5A3 and TMEM15 deficiencies were accompanied by altered N-glycosylation as demonstrated by abnormal glycosylation of serum transferrin $[23,25]$. Clinically, it is interesting to note that the DHDDS deficiency caused by the K42E substitution yielded a form of nonsyndromic retinitis pigmentosa, while the polyprenol reductase and dolichol kinase defects led to severe multi-organ dysfunctions. It is possible that the K42E substitution only slightly decreases DHDDS activity, thereby leading to a limited pathology. Alternatively, it is possible that other enzymes may replace DHDDS in polyprenol elongation or that polyprenol may be taken up or recycled from dietary sources if the rate of biosynthesis would be decreased. The identification of additional DHDDS mutations will certainly clarify this question.

\subsection{Defects of lipid-linked oligosaccharide biosynthesis}

After formation of Dol-P at the cytosolic side of the ER membrane, a series of glycosyltransferases add monosaccharides stepwise to complete the mature lipid-linked oligosaccharide (LLO) Dol-PP$\mathrm{GlcnAc}_{2} \mathrm{Man}_{9} \mathrm{Glc}_{3}$ (Fig. 2). The first glycosyltransferase along this pathway is the UDP-GlcNAc:Dol-P GIcNAc-phosphotransferase (DPAGT1, OMIM ID: 191350) that transfers GIcNAc-P to Dol-P, thereby yielding Dol-PP-GIcNAc. The subsequent cytosolically-oriented enzymes transfer GIcNAc and Man residues using the donor substrates UDP-GIcNAc and GDP-Man. After translocation of the intermediate LLO Dol-PP-GICNAC $2 \mathrm{Man}_{5}$ into the ER-Iumen, other glycosyltransferases elongate LLO further using Dol-P-Man and Dol-P-Glc as substrates. Mutations have been identified in nearly all ERglycosyltransferase genes involved in LLO biosynthesis. An extensive description of all mutations and of their effects on ER-glycosylation is provided in the recent review of Haeuptle and Hennet [7]. Clinically, alterations of LLO biosynthesis lead to broad neurological diseases of varying severity. The most frequent symptoms are psychomotor retardation, ataxia, hypotonia, seizures and coagulopathies.

Defective glycosyltransferases are not the only causes of abnormal LLO biosynthesis. Decreased availability of the substrate Dol-P-Man, such as caused by mutations in the Dol-P-Man synthase subunit genes DPM1 (OMIM ID: 603503) [26, 27] and DPM3 (OMIM ID: 605951) [28] (Fig. 1, 2), lead to the accumulation of the incomplete LLO and thereby to incomplete N-glycosylation site occupancy on newly synthesized glycoproteins. The MPDU1 (OMIM ID: 604041) and RFT1 (OMIM ID: 611908) proteins are also involved in LLO biosynthesis, although their exact functions remain unclear. Mutations in both genes lead to accumulation of incomplete LLO, yet through different mechanisms. The transmembraneous MPDU1 protein likely increases the accessibility of Dol-P-Man and Dol-P-Glc 
substrates to the glycosyltransferases embedded in the ER membrane [29]. Accordingly, mutations in the MDPU1 gene lead to the accumulation of Dol-PP-GIcNAc $\mathrm{Man}_{5}$ and Dol-PP-GIcNAc $\mathrm{Man}_{9}$ due to limited access to the corresponding donor substrates [30,31]. The RFT1 protein facilitates the translocation of the intermediate LLO Dol-PP-GICNAc $\mathrm{Man}_{5}$ from the cytosolic to the luminal side of the ER membrane, possibly acting as a flippase [32]. The accumulation of the LLO Dol-PPGlcNAc $_{2} \mathrm{Man}_{5}$ is also typically found in cases of RFT1 deficiency $[33,34]$. Mutations in the MPDU1 and RTF1 genes yield forms of CDG with clinical features similar to those encountered in other types of defective LLO assembly [7].

Defects leading to decreased availability of Dol-P-Man do not only impair N-glycosylation but also Omannosylation and the biosynthesis of the GPI anchor. Along this line, deficiency of DPM1 indeed leads to decreased formation of GPI-anchored proteins, such as the complement protecting protein CD59 [26].

\subsection{Defects of $\mathrm{N}$-glycosylation}

\subsubsection{Oligosaccharyltransferase subunits}

The transfer of the complete LLO Dol-PP-GICNAC $\mathrm{Man}_{9} \mathrm{Gl}_{3}$ to nascent proteins is mediated by the oligosaccharyltransferase (OST) complex (Fig. 2), which includes at least seven subunits [35]. The N33/TUSC3 (OMIM ID: 601385) and the IAP/MAGT1 (OMIM ID: 300715) genes encode paralogous OST subunits that are active as oxidoreductases [36]. Mutations in these genes have been identified in few cases of nonsyndromic mental retardation $[37,38]$. The impact of the N33/TUSC3 and IAP mutations on OST activity is unclear. It is likely that they only affect the N-glycosylation of a restricted set of brain glycoproteins since serum glycoproteins were shown to be normally $\mathrm{N}$-glycosylated in the corresponding patients [37].

\subsubsection{Glucosidase I}

$\mathrm{N}$-glycans are first trimmed in the ER by the two glucosidase enzymes GCS1 and GCS2 (Fig. 3). A single case of glucosidase I GCS1 (OMIM ID: 601336) deficiency has been reported yet, which was linked to the compound heterozygous mutations R486T and F652L. The resulting loss of N-glycan trimming was accompanied with a severe pathology, featuring dysmorphism, hypotonia and leading to the death of the affected infant [39].

\subsubsection{ER mannosidase I}

The severe disease resulting from glucosidase I deficiency contrasts with another defect of N-glycan trimming, which is caused by mutations in the ER-localized mannosidase I enzyme (MAN1B1, OMIM ID: 604346). This mannosidase acts on the N-glycan core after removal of the three terminal Glc residues, thereby yielding $\mathrm{GlCNAc}_{2} \mathrm{Man}_{8}$ (Fig. 3). This trimming step is required for the transition of 
folded glycoproteins from the ER to the Golgi apparatus. Abnormal trimming is likely to affect the elimination of unfolded glycoproteins through the ER-associated degradation (ERAD) pathway [40]. MAN1B1 mutations have been described in twelve patients originating from five consanguineous Iranian and Pakistanis families. The impairment of these patients was limited to intellectual disabilities such as delayed speech and mild dysmorphic features [41].

\subsection{4. $\beta 1-2$ GIcNAc-transferase II}

After trimming, N-glycans undergo elongation and branching in the Golgi apparatus (Fig. 3). A severe disease of glycosylation occurs when the branching $\beta 1-2$ GIcNAc-transferase MGAT2 (OMIM ID: 602616) is affected. A deficiency of MGAT2 has only been reported in four patients, who featured severe psychomotor retardation, facial dysmorphic features, osteopenia and epilepsy among others $[42,43]$.

\subsection{5. $\beta 1-4$ Gal-transferase I}

No other branching defect has been reported yet, but a defect of the elongating $\beta 1-4 \mathrm{Gal}-$ transferase-1 B4GALT1 enzyme (OMIM ID: 137060) has also been associated with a form of CDG. A case of B4GALT1 deficiency has been reported by Hansske et al. [44], which was caused by a single base insertion resulting in the translation of a truncated B4GALT1 protein. The clinical features observed in this case of B4GALT1 deficiency were typical of CDG, showing hypotonia, Dandy-Walker malformation, coagulopathy but no psychomotor retardation. The same mutation was identified in a second patient, who presented similar symptoms, although including hepatomegaly and lacking Dandy-Walker malformation [45]. Note worthily, the B4GALT1 enzyme is also involved in the galactosylation of different classes of glycans, meaning that the phenotypes associated with B4GALT1 deficiency are not solely due to abnormal N-glycosylation (Fig. 3).

\subsection{6. $\alpha 2-3$ Sia-transferase III}

The negatively charged carbohydrate Sia is often found at the terminal position of glycan chains. The addition of Sia is catalyzed by a family of 20 sialyltransferase enzymes, which transfer Sia via $\alpha 2-3$, $\alpha 2-6$ and $\alpha 2-8$ linkages to various glycan acceptors [46]. The disruption of sialyltransferase genes in mice often results in immune and hematologic phenotypes [47-49]. Very recently, mutations in the a2-3 sialyltransferase gene ST3GAL3 (OMIM ID: 606494) have been associated with nonsyndromic mental retardation [50]. The exact impact of ST3GAL3 deficiency on brain glycoproteins remains to be established. Based on prominent expression of the ST3GAL3 gene in skeletal muscle and considering it low expression in brain tissue [51], it can be assumed that other $\alpha 2-3$ sialyltransferases can compensate for the loss of ST3GAL3 activity in most tissues. Although ST3GAL3 deficiency is 
discussed in the context of $\mathrm{N}$-glycosylation (Fig. 3), other types of glycosylation are likely to be affected by this gene defect, too.

\subsection{Defects of O-GalNAc glycosylation}

\subsubsection{Polypeptide GalNAc-transferase-3}

Mucin type O-GalNAc glycosylation is initiated by the action of a family of polypeptide GalNActransferases localized in the cis-Golgi apparatus [52] (Fig. 4). Because this large family of polypeptide GalNAc-transferases ensures a functional redundancy in the O-glycosylation of protein substrates, a disease caused by mutations in a specific polypeptide GalNAc-transferase gene is difficult to predict based on clinical features. Accordingly, the association of mutations in the polypeptide GalNActransferase-3 gene (GALNT3, OMIM ID: 601756) with the disease tumoral calcinosis was surprising [53]. The primary cause of tumoral calcinosis is a deficiency of the hormone fibroblast growth factor23 (FGF23), which regulates the calcium and phosphate metabolism [54]. FGF23 is a glycoprotein carrying O-GaINAc glycans close to a subtilisin-like proprotein convertase recognition site. The Oglycan at position Thr178 prevents the proteolytic cleavage of FGF23 and thereby its inactivation [55]. The GALNT3 enzyme is essential for the O-glycosylation of FGF23, thereby explaining the phenotypic similarity resulting from either FGF23 or GALNT3 deficiency.

\subsubsection{Polypeptide GalNAc-transferase-12}

Another polypeptide GalNAc-transferase isoform has been implied in the etiology of colon cancer. Heterozygous mutations in the polypeptide GalNAc-transferase-12 gene (GALNT12, OMIM ID: 610290) (Fig. 4) have been reported in several individuals with colon cancer [56]. Some of the mutations were detected in the germline of the patients, whereas other mutations were somatic and localized to the tumors themselves. Although it is unclear whether the decreased GALNT12 activity affects O-glycosylation in colon tissue, increased antibody reactivity towards unglycosylated MUC1 mucin protein was found in several colon tumors [56].

\subsubsection{Core $1 \beta 1-3$ Gal-transferase}

In contrast to the large family of polypeptide GalNAc-transferases, a single core $1 \beta 1-3 \mathrm{Gal}$ transferase catalyzes the extension of O-GaINAc (Fig. 4). The core $1 \beta 1-3 \mathrm{Gal}$-transferase enzyme is also unique among Golgi glycosyltransferases in respect to its folding. In fact, the core $1 \beta 1-3 \mathrm{Gal}-$ transferase protein requires a specific chaperone called COSMC (OMIM ID: 300611), which interacts with the core $1 \beta 1$-3Gal-transferase polypeptide in the ER [57]. Mutations in the human COSMC gene have been reported to cause the Tn-syndrome [58], a mild hematological disorder characterized by a mosaic presentation of bare GaINAc, also called Tn-antigen, on blood cells. Such Tn-positive cells arise from hemopoietic stem cells harboring a mutated Cosmc gene and lacking core 1 B1-3Gal- 
transferase activity. Persons with a Tn-syndrome are healthy and are only affected by a mild hemolytic anemia and decreased platelet and leukocyte counts.

\subsection{Defects of O-Man glycosylation}

Defects of O-mannosylation belong to dystroglycanopathies, since $\alpha$-dystroglycan is the main carrier of O-Man chains in vertebrates. $\alpha$-Dystroglycan carries multiple O-Man and O-GalNAc glycans, which contribute to the binding of $\alpha$-dystroglycan to extracellular matrix proteins such as laminin-2. The clinical hallmark of dystroglycanopathies are pathology of the muscle, eye and brain [59]. The first disease associated with O-mannosylation was reported 1998, when mutations in the putative glycosyltransferase Fukutin were identified as a cause of Fukuyama-type congenital muscular dystrophy [60]. Other forms of congenital muscular dystrophies were later associated with additional glycosyltransferases involved in O-mannosylation. To date, deficiency in POMT1 (OMIM ID: 607423), POMT2 (OMIM ID: 607439), POMGNT1 (OMIM ID: 606822), LARGE (OMIM ID: 603590), Fukutin (OMIM ID: 607440) and Fukutin-related protein (FKRP) (OMIM ID: 606596) (Fig. 4) have been associated with the Walker-Warburg syndrome, Muscle-Eye-Brain disease, Fukuyama-type congenital muscular dystrophy and Limb Girdle muscular dystrophy. Mutations in the core glycosyltransferase genes POMT1 and POMT2 are mainly found in the most severe forms of congenital muscular dystrophies such as the Walker-Warburg syndrome [61, 62]. However, the severity of the disease depends more on the level of residual activity of the enzymes than on the position of the mutated gene along the glycosylation pathway. Accordingly, mutations in all glycosyltransferase genes involved in O-Man glycan biosynthesis have been associated with severe forms of congenital muscular dystrophy. To date, no enzymatic activity could be demonstrated for the putative glycosyltransferases Fukutin and FKRP. In addition to its role in muscle cell adhesion, $\alpha$ dystroglycan is also involved in the migration of cortical neurons [63] and in retinal development [64]. The dystroglycan-laminin complex is important for the formation of the glia limitans, which prevents neurons to migrate into the subarachnoid space. Accordingly, under conditions of abnormal $\alpha$-dystroglycan glycosylation, neurons overshoot across the marginal zone, thereby leading to a condition referred to as "cobblestone" lissencephaly [65].

\subsection{Defects of O-Fuc glycosylation}

\subsubsection{Lunatic fringe}

O-Fucosylation is found specifically on epidermal growth factor (EGF)-like domains and thrombospondin type 1 (TSP1) domains [66]. The transfer of Fuc to selected serine and threonine residues on EGF-like and TSP1 domains takes place in the ER and uses GDP-Fuc as donor substrate. EGF-like domains are often found repeated on several proteins. For example, the Notch receptor has 
36 EGF-like domains and its ligands Delta1 and Jagged1 have respectively 8 and 16 EGF-like domains [67]. Other proteins like coagulation factors and signaling proteins also contain EGF-like domains that are likely to be O-fucosylated. The role of O-fucosylation in mammalian development is underlined by the skeletal defects resulting from abnormal vertebral segmentations. Accordingly, mutations in the lunatic fringe gene (LFNG, OMIM ID: 602576) (Fig. 4) encoding a $\beta 1-3$ GlcNAc-transferase elongating O-Fuc have been described in cases of spondylocostal dysostosis [68].

\subsection{2. $\beta 1-3$ Glc-transferase}

Another disease of O-fucosylation, the Peters-Plus syndrome, is caused by mutations of the $\beta 1-3 \mathrm{Glc}-$ transferase gene (B3GALTL, OMIM ID: 610308) acting on TSP1-linked O-Fuc [69] (Fig. 4). The disease is characterized by eye chamber defects, developmental delay and growth impairment. Patients have short stature and usually do not exceed $1.5 \mathrm{~m}$. A typical feature of Peters-Plus syndrome is keratolenticular adhesion, which is a caused by a developmental defect of the lens and anterior eye chamber [70]. However, the O-fucosylated glycoprotein involved in this abnormal development and the mechanisms underlying the defect are still unknown.

\subsection{Defects of glycosaminoglycan biosynthesis}

\subsubsection{Xyl $\beta 1-4$ Gal-transferase}

The core structure of glycosaminoglycan (GAG) chains is unique among glycans featuring a Xyl residue $\beta$-linked to serine. The GAG core also includes two Gal units and a GlcA unit. The first Gal residue is added to Xyl by the $\beta 1-4$ Gal-transferase XGPT1 (OMIM ID: 604327) (Fig. 5), which is defective in the progeroid form of the Ehlers-Danlos syndrome $[71,72]$. This disease is characterized by mental retardation and connective tissues abnormalities such as loose skin, osteopenia and joint hypermobility. Only few cases of the disease have been reported to date.

\subsection{2. $\beta 1-3$ GIcA-transferase}

Another defect of GAG core biosynthesis has been described recently. A mutation in the $\beta 1-3 \mathrm{GlcA}$ transferase gene (B3GAT3, OMIM ID: 606374) (Fig. 5) was found in patients presenting with short stature, congenital heart defects and joint dislocations [73]. The mutant B3GAT3 enzyme showed decreased activity, which reduced the level of heparan, chondroitin and dermatan sulfate chains on proteoglycans. Some proteoglycans like decorin were even secreted devoid of its single dermatan sulfate chain. The disease in question was also previously known as autosomal recessive Larsen-like syndrome [74].

\subsubsection{EXT1/EXT2 transferase}

So far, defects of GAG chain polymerization have also been associated with two diseases. The first one is called multiple hereditary exostoses and is characterized by protrusions of bone material 
mainly emerging at the end of long bones and originating from benign cartilage tumors. Multiple hereditary exostoses is an autosomal dominant disease caused by heterozygous mutations in the EXT1 (OMIM ID: 608177) and EXT2 (OMIM ID: 608210) genes [75]. The EXT1 and EXT2 proteins form an oligomeric complex that mediates the polymerization of heparan sulfate chains [76] (Fig. 5). The inclusion of a mutant EXT1 or EXT2 subunit to the complex decreases the polymerase activity and leads to a significant reduction of heparan sulfate chains in tissues, in which the amount of such chains is critical, such as in bones. Multiple hereditary exostoses is a rather frequent condition with an incidence of 1 in 50,000 individuals.

\subsubsection{Chondroitin synthase-1}

The second disease of GAG chain polymerization is called Temtamy preaxial brachydactyly syndrome [77], which is caused by mutations in the chondroitin synthase-1 gene (CHSY1, OMIM ID: 608183). The chondroitin synthase-1 enzyme contains two catalytic domains with $\beta 1-3$ GlcA-transferase and 11-4 GalNAc-transferase activities (Fig. 5). Most CHSY1 mutations identified in patients with Temtamy preaxial brachydactyly syndrome are deletions leading to truncated proteins and probably complete loss of enzymatic activity [77]. The clinical picture of the syndrome is characterized by a form of digit malformation called preaxial brachydactyly but also by mental and growth retardation, facial dysmorphism and hearing loss. The loss of CHSY1 activity in Temtamy preaxial brachydactyly syndrome suggests that additional chondroitin synthase isoforms, such as CHSY2 [78] and CHSY3 [79], are likely to compensate for the inactive CHSY1 enzyme.

\subsubsection{Sulfotransferases}

GAG chains are extensively modified by sulfation. Three diseases are associated with defective sulfation of carbohydrates in GAG chains. The first disease is Omani type spondylepiphyseal dysplasia [80], which is caused by a deficiency of the chondroitin 6-O sulfotransferase enzyme CHST3 (OMIM ID: 603799) catalyzing the 6-O sulfation of GalNAc found in chondroitin and dermatan sulfate chains. The symptoms of Omani type spondylepiphyseal dysplasia are typical of connective tissue disorders with short stature, skeletal dysplasia, kyphoscoliosis and arthritic joints. Mutations in the dermatan 4-sulfotransferase-1 CHST14 gene (OMIM ID: 608429) lead to the musculocontractural type of EhlersDanlos syndrome [81], which is characterized by severe manifestations such as craniofacial dysmorphism, kyphoscoliosis, hypotonia and joint hypermobility. The CHST14 enzyme transfers sulfate to the 4-O position of GalNAc residues flanked on both sides by IdoA. This strict acceptor recognition explains why this sulfotransferase is specific for dermatan sulfate and does not affect chondroitin sulfate chains. The third sulfation defect affects the GIcNAc-6-sulfotransferase CHST6 gene (OMIM ID: 605294), which is involved in the sulfation of keratan sulfate chains. The CHST6 gene is expressed in many cell types but the clinical features of GlcNAc-6-O sulfotransferase deficiency are 
limited to the eye, resulting in a progressive opacity of the cornea, a condition referred to as macular corneal dystrophy [82].

\subsection{Defects of glycolipid biosynthesis}

\subsubsection{GM3 synthase}

Only one defect of glycosphingolipid biosynthesis has been described to date. A form of infantile epilepsy occurring in the Amish community has been linked to a deficiency of the ganglioside GM3 caused by mutations in the $\alpha 2-3$ sialyltransferase ST3GAL5 gene (OMIM ID: 604402) (Fig. 6). The loss of $\mathrm{GM} 3$ is related to symptoms like failure to thrive, psychomotor retardation, hypotonia, epilepsy, and blindness [83].

\subsubsection{PIGA protein}

Three gene defects are known to impair the assembly of the GPI anchor. The PIGA gene encodes a subunit of the complex initiating GPI anchor biosynthesis (Fig. 6). Somatic mutations in the X-linked PIGA gene (OMIM ID: 311770) arising in hemopoietic stem cells lead to the hemolytic anemia paroxysmal nocturnal hemoglobinuria (PNH) [84]. The absence of GPI-anchored proteins renders red blood cells sensitive to complement-mediated lysis, which explains the increased hemoglobin levels in the urine. PHN is also associated with increased incidence of leukemia and increased thrombotic episodes [85].

\subsubsection{PIGM protein}

A hypomorphic mutation in the promoter of PIGM mannosyltransferase gene (OMIM ID: 610273) has been also identified as a cause of low GPI expression. The PIGM enzyme transfers the first Man residue to the growing GPI core in the ER lumen [86] (Fig. 6). To date, three cases of PIGM deficiency originating from two families have been described [87]. The patients showed increased thrombosis but no signs of hemolysis, although the levels of several GPI anchored proteins were reduced on hematopoietic cells. Besides the hematologic presentation, absence seizures were also observed in the affected children.

\subsubsection{PIGV protein}

The PIGV gene (OMIM ID: 610274) encodes the ER-localized mannosyltransferase adding the second mannose to the GPI core [88]. PIGV deficiency is associated with a form of hyperphosphatasia and severe mental retardation, which is also referred to as Mabry syndrome [89]. Five missense mutations leading to amino acid substitutions in conserved residues of the PIGV enzyme have been identified in nine patients so far $[90,91]$. Elevated serum alkaline phosphatase levels are also typically found in Mabry syndrome. This feature results from the secretion of the alkaline phosphatase enzyme that is normally anchored to the cell surface through GPI [92]. 


\subsubsection{PIGN protein}

A defect in the addition of the first ethanolamine phosphate group to GPI has been recently associated with the multiple congenital anomalies-hypotonia-seizures syndrome [93]. The GPI ethanolamine phosphate transferase-1 enzyme is encoded by the PIGN gene (OMIM ID: 606097) (Fig. 6), in which the homozygous mutation 2126G>A was identified in seven patients from a consanguineous Middle-eastern family [93]. The patients presented with severe neurological alterations, seizures, dysmorphic features and multiple organ impairments leading to infantile lethality.

\subsection{Defects of nucleotide-sugar transport}

\subsubsection{GDP-Fuc transporter}

Disorders of nucleotide-sugar transporters impact on multiple classes of glycosylation. Three defects of nucleotide-sugar transport have been described to date. The first one was related to mutations in the Golgi GDP-Fuc transporter gene (SLC35C1, OMIM ID: 605881), which leads to decreased protein fucosylation. Such fucosylated proteins are essential for the trafficking of leukocytes through the body and decreased fucosylation leads to impaired leukocyte extravasation and thus to a form of immunodeficiency called leukocyte adhesion deficiency type II (LAD2) or CDG-IIc [94]. In addition to immunodeficiency, the affected patients show short stature, mild dysmorphism and psychomotor retardation. Considering the residual transporter activity enabled by most mutations in the Golgi GDP-Fuc transporter gene, the fucosylation defect and the resulting immune disorder can be corrected by dietary fucose supplementation [95].

\subsubsection{CMP-Sia transporter}

Mutations in the CMP-Sia transporter gene (SLC35A1, OMIM ID: 605634) have only been found in a single infant patient presenting with a severe bleeding disorder designated SLC35A1-CDG or CDG-IIf [96]. The patient was compound heterozygous for two inactive SLC35A1 alleles, which resulted in decreased protein sialylation on hematopoietic cells, whereas several serum proteins, like transferrin, were surprisingly unaffected.

\subsubsection{UDP-GICA/GalNAc transporter}

Some transporters mediate the transport of two or more nucleotide sugars. The SLC35D1 gene (OMIM ID: 610804) encodes such a multi-specific transporter, which mediates the transfer of both UDP-GIcA and UDP-GalNAc into the ER and Golgi apparatus [97]. Both substrates are critical for the biosynthesis of chondroitin sulfate chains, as demonstrated by the reduction of chondroitin sulfate on proteoglycans isolated from SLC35D1-null mice [98]. Mutations in the SLC35D1 gene have also been reported in humans, namely in cases of Schneckenbecken dysplasia (OMIM 269250). The 
disease is characterized by severe skeletal abnormalities caused by altered cartilage and bone formation. Schneckenbecken dysplasia leads to neonatal lethality, which is also frequently observed in SLC35D1-null mice. Seven allelic variants of the SLC35D1 gene have been identified in Schneckenbecken dysplasia so far [99].

\subsection{Defects of vesicular transport}

\subsubsection{COG complex}

The proper localization of glycosyltransferases and nucleotide-sugar transporters is required for normal glycosylation. Several tethering factors and vesicular transport proteins are involved in the regulation of glycosyltransferase localization [100]. Accordingly, the defective assembly of the Conserved Oligomeric Golgi (COG) complex leads to mislocalization of several glycosyltransferases and thereby to defects in multiple classes of glycosylation [101]. To date, mutations have been found in five of the eight subunit genes of the complex, namely in the COG1 (OMIM ID: 606973) [102], COG4 (OMIM ID: 606976) [103], COG5 (OMIM ID: 606821) [104], COG7 (OMIM ID: 606978) [105] and COG8 (OMIM ID: 606979) subunits [106]. The clinical pictures of COG defects are variable but in general similar to those of other types of CDG with mainly neuromuscular involvements, dysmorphia, psychomotor retardation and coagulopathy [107].

\subsubsection{SEC23B protein}

Congenital dyserythropoietic anemia type II (CDAN2), also called hereditary erythroblastic multinuclearity with a positive acidified serum (HEMPAS), was promptly recognized to be associated with abnormal N-glycosylation [108]. First shown to be related to low $\beta 1-2$ GlcNAc-transferase II activity [109] and later to low a-mannosidase-II expression [110], CDAN2 has finally been mapped to the SEC23B gene (OMIM ID: 610512) [111]. The SEC23B protein is part of the coat protein complex COPII, which transport proteins from the ER to the Golgi apparatus.

\subsubsection{ATP6VOA2 protein}

A combined defect of $\mathrm{N}$-glycosylation and O-glycosylation was recognized in a form of cutis laxa characterized by wrinkled skin, osteopenia, facial dysmorphism, hypotonia and developmental delay [112]. Using linkage analysis, the defect was localized to the ATP6VOA2 gene (OMIM ID: 611716), which encodes a subunit of a Golgi $\mathrm{H}^{+}$-ATPase pump possibly involved in $\mathrm{pH}$ regulation along the secretory pathway [113]. It is presently unclear whether the putative $\mathrm{pH}$ shift affects the localization or the activity of Golgi resident glycosyltransferases.

\section{Conclusion}


The simple analysis of serum transferrin by isoelectric focusing led to the discovery of a large family of $\mathrm{N}$-glycosylation disorders. Because adequate biomarkers are not available for other classes of glycosylation, defects of O-glycosylation, GAG and glycolipid biosynthesis have long remained confined to few examples mainly identified by genetic linkage analysis. The emergence of new genome sequencing techniques will definitively boost the pace of discovery and unravel new genetic defects affecting glycosylation. In spite of this advancement, the challenge will still be to understand the mechanisms underlying the impact of gene defects on glycosylation. Whereas defective glycosyltransferases are relatively easily associated with specific glycosylation pathways, the effect of vesicular transport proteins and signaling proteins will require more work to be addressed. Nevertheless, the knowledge gathered through the investigation of diseases of glycosylation definitively improves the comprehension of glycosylation pathways and of their complex regulations.

\section{Acknowledgements}

I thank the two reviewers of this article for their valuable input. This work was supported by the Swiss National Foundation grant 310030-129633 to T. Hennet.

\section{References}

[1] J. Jaeken, H. Stibler, B. Hagberg, The carbohydrate-deficient glycoprotein syndrome. A new inherited multisystemic disease with severe nervous system involvement, Acta Paediatr Scand Suppl, 375 (1991) 1-71.

[2] M. Aebi, A. Helenius, B. Schenk, R. Barone, A. Fiumara, E.G. Berger, T. Hennet, T. Imbach, A. Stutz, C. Bjursell, A. Uller, J.G. Wahlstrom, P. Briones, E. Cardo, P. Clayton, B. Winchester, V. Cormier-Dalre, P. de Lonlay, M. Cuer, T. Dupre, N. Seta, T. de Koning, L. Dorland, F. de Loos, L. Kupers, Carbohydratedeficient glycoprotein syndromes become congenital disorders of glycosylation: an updated nomenclature for CDG. First International Workshop on CDGS, Glycoconj.J., 16 (1999) 669-671.

[3] J. Jaeken, T. Hennet, G. Matthijs, H.H. Freeze, CDG nomenclature: time for a change!, Biochim Biophys Acta, 1792 (2009) 825-826.

[4] H. Stibler, S. Borg, C. Allgulander, Clinical significance of abnormal heterogeneity of transferrin in relation to alcohol consumption, Acta Med Scand, 206 (1979) 275-281. 
[5] J. Jaeken, H.G. van Eijk, C. van der Heul, L. Corbeel, R. Eeckels, E. Eggermont, Sialic acid-deficient serum and cerebrospinal fluid transferrin in a newly recognized genetic syndrome, Clin.Chim.Acta, 144 (1984) 245-247.

[6] H. Stibler, J. Jaeken, Carbohydrate deficient serum transferrin in a new systemic hereditary syndrome, Arch Dis Child, 65 (1990) 107-111.

[7] M.A. Haeuptle, T. Hennet, Congenital disorders of glycosylation: an update on defects affecting the biosynthesis of dolichol-linked oligosaccharides, Human Mutation, in press (2009).

[8] E. Schollen, S. Kjaergaard, E. Legius, M. Schwartz, G. Matthijs, Lack of Hardy-Weinberg equilibrium for the most prevalent PMM2 mutation in CDG-la (congenital disorders of glycosylation type la), Eur.J.Hum.Genet., 8 (2000) 367-371.

[9] C. Thiel, T. Lubke, G. Matthijs, K. von Figura, C. Korner, Targeted disruption of the mouse phosphomannomutase 2 gene causes early embryonic lethality, Mol Cell Biol, 26 (2006) 5615-5620.

[10] J. Jaeken, Komrower Lecture. Congenital disorders of glycosylation (CDG): it's all in it!, J Inherit Metab Dis, 26 (2003) 99-118.

[11] S. Grunewald, G. Matthijs, J. Jaeken, Congenital disorders of glycosylation: a review, Pediatr Res, 52 (2002) 618-624.

[12] R. Niehues, M. Hasilik, G. Alton, C. Körner, M. Schiebe-Sukumar, H.G. Koch, K.P. Zimmer, R. Wu, E. Harms, K. Reiter, K. von Figura, H.H. Freeze, H.K. Harms, T. Marquardt, Carbohydrate-deficient glycoprotein syndrome type lb. Phosphomannose isomerase deficiency and mannose therapy., J.Clin.Invest., 101 (1998) 1414-1420.

[13] J. Senderek, J.S. Muller, M. Dusl, T.M. Strom, V. Guergueltcheva, I. Diepolder, S.H. Laval, S. Maxwell, J. Cossins, S. Krause, N. Muelas, J.J. Vilchez, J. Colomer, C.J. Mallebrera, A. Nascimento, S. Nafissi, A. Kariminejad, Y. Nilipour, B. Bozorgmehr, H. Najmabadi, C. Rodolico, J.P. Sieb, O.K. Steinlein, B. Schlotter, B. Schoser, J. Kirschner, R. Herrmann, T. Voit, A. Oldfors, C. Lindbergh, A. Urtizberea, M. von der Hagen, A. Hubner, J. Palace, K. Bushby, V. Straub, D. Beeson, A. Abicht, H. Lochmuller, Hexosamine biosynthetic pathway mutations cause neuromuscular transmission defect, Am J Hum Genet, 88 (2011) 162-172.

[14] N.E. Zachara, G.W. Hart, Cell signaling, the essential role of O-GlcNAc!, Biochim Biophys Acta, 1761 (2006) 599-617.

[15] K.S. Lau, E.A. Partridge, A. Grigorian, C.I. Silvescu, V.N. Reinhold, M. Demetriou, J.W. Dennis, Complex $\mathrm{N}$-glycan number and degree of branching cooperate to regulate cell proliferation and differentiation, Cell, 129 (2007) 123-134. 
[16] D.C. Love, J.A. Hanover, The hexosamine signaling pathway: deciphering the "O-GlcNAc code", Sci STKE, 2005 (2005) re13.

[17] S.O. Reinke, G. Lehmer, S. Hinderlich, W. Reutter, Regulation and pathophysiological implications of UDP-GIcNAc 2-epimerase/ManNAc kinase (GNE) as the key enzyme of sialic acid biosynthesis, Biol Chem, 390 (2009) 591-599.

[18] I. Eisenberg, N. Avidan, T. Potikha, H. Hochner, M. Chen, T. Olender, M. Barash, M. Shemesh, M. Sadeh, G. Grabov-Nardini, I. Shmilevich, A. Friedmann, G. Karpati, W.G. Bradley, L. Baumbach, D. Lancet, E.B. Asher, J.S. Beckmann, Z. Argov, S. Mitrani-Rosenbaum, The UDP-N-acetylglucosamine 2epimerase/N-acetylmannosamine kinase gene is mutated in recessive hereditary inclusion body myopathy, Nat.Genet., 29 (2001) 83-87.

[19] P.J. Savelkoul, I. Manoli, S.E. Sparks, C. Ciccone, W.A. Gahl, D.M. Krasnewich, M. Huizing, Normal sialylation of serum N-linked and O-GalNAc-linked glycans in hereditary inclusion-body myopathy, Mol Genet Metab, 88 (2006) 389-390.

[20] H. Stibler, U. von Dobeln, B. Kristiansson, C. Guthenberg, Carbohydrate-deficient transferrin in galactosaemia, Acta Paediatr, 86 (1997) 1377-1378.

[21] L. Zelinger, E. Banin, A. Obolensky, L. Mizrahi-Meissonnier, A. Beryozkin, D. Bandah-Rozenfeld, S. Frenkel, T. Ben-Yosef, S. Merin, S.B. Schwartz, A.V. Cideciyan, S.G. Jacobson, D. Sharon, A missense mutation in DHDDS, encoding dehydrodolichyl diphosphate synthase, is associated with autosomalrecessive retinitis pigmentosa in Ashkenazi Jews, Am J Hum Genet, 88 (2011) 207-215.

[22] S. Zuchner, J. Dallman, R. Wen, G. Beecham, A. Naj, A. Farooq, M.A. Kohli, P.L. Whitehead, W. Hulme, I. Konidari, Y.J. Edwards, G. Cai, I. Peter, D. Seo, J.D. Buxbaum, J.L. Haines, S. Blanton, J. Young, E. Alfonso, J.M. Vance, B.L. Lam, M.A. Pericak-Vance, Whole-exome sequencing links a variant in DHDDS to retinitis pigmentosa, Am J Hum Genet, 88 (2011) 201-206.

[23] V. Cantagrel, D.J. Lefeber, B.G. Ng, Z. Guan, J.L. Silhavy, S.L. Bielas, L. Lehle, H. Hombauer, M. Adamowicz, E. Swiezewska, A.P. De Brouwer, P. Blumel, J. Sykut-Cegielska, S. Houliston, D. Swistun, B.R. Ali, W.B. Dobyns, D. Babovic-Vuksanovic, H. van Bokhoven, R.A. Wevers, C.R. Raetz, H.H. Freeze, E. Morava, L. Al-Gazali, J.G. Gleeson, SRD5A3 is required for converting polyprenol to dolichol and is mutated in a congenital glycosylation disorder, Cell, 142 (2010) 203-217.

[24] L. Al-Gazali, J. Hertecant, K. Algawi, H. El Teraifi, M. Dattani, A new autosomal recessive syndrome of ocular colobomas, ichthyosis, brain malformations and endocrine abnormalities in an inbred Emirati family, Am J Med Genet A, 146 (2008) 813-819. 
[25] C. Kranz, C. Jungeblut, J. Denecke, A. Erlekotte, C. Sohlbach, V. Debus, H.G. Kehl, E. Harms, A. Reith, S. Reichel, H. Grobe, G. Hammersen, U. Schwarzer, T. Marquardt, A defect in dolichol phosphate biosynthesis causes a new inherited disorder with death in early infancy, Am J Hum Genet, 80 (2007) 433-440.

[26] T. Imbach, B. Schenk, E. Schollen, P. Burda, A. Stutz, S. Grünewald, N. Bailie, M.D. King, J. Jaeken, G. Matthijs, E.G. Berger, M. Aebi, T. Hennet, Deficiency of dolichol-phosphate-mannose synthase-1 causes congenital disorder of glycosylation (CDG) type-le, J.Clin.Invest., 105 (2000) 233-239.

[27] S. Kim, V. Westphal, G. Srikrishna, D.P. Mehta, S. Peterson, J. Filiano, P.S. Karnes, M.C. Patterson, H.H. Freeze, Dolichol phosphate mannose synthase (DPM1) mutations define congenital disorder of glycosylation le (CDG-le), J.Clin.Invest., 105 (2000) 191-198.

[28] D.J. Lefeber, J. Schonberger, E. Morava, M. Guillard, K.M. Huyben, K. Verrijp, O. Grafakou, A. Evangeliou, F.W. Preijers, P. Manta, J. Yildiz, S. Grunewald, M. Spilioti, C. van den Elzen, D. Klein, D. Hess, H. Ashida, J. Hofsteenge, Y. Maeda, L. van den Heuvel, M. Lammens, L. Lehle, R.A. Wevers, Deficiency of Dol-P-Man synthase subunit DPM3 bridges the congenital disorders of glycosylation with the dystroglycanopathies, Am J Hum Genet, 85 (2009) 76-86.

[29] M. Anand, J.S. Rush, S. Ray, M.A. Doucey, J. Weik, F.E. Ware, J. Hofsteenge, C.J. Waechter, M.A. Lehrman, Requirement of the Lec35 gene for all known classes of monosaccharide-P- dolicholdependent glycosyltransferase reactions in mammals, Mol.Biol.Cell, 12 (2001) 487-501.

[30] B. Schenk, T. Imbach, C.G. Frank, C.E. Grubenmann, G.V. Raymond, H. Hurvitz, A. Raas-Rotschild, A.S. Luder, J. Jaeken, E.G. Berger, G. Matthijs, T. Hennet, M. Aebi, MPDU1 mutations underlie a novel human congenital disorder of glycosylation (CDG), designated type If, J.Clin.Invest., 108 (2001) 16871695.

[31] C. Kranz, J. Denecke, M.A. Lehrman, S. Ray, P. Kienz, G. Kreissel, D. Sagi, J. Peter-Katalinic, H.H. Freeze, T. Schmid, S. Jackowski-Dohrmann, E. Harms, T. Marquardt, A mutation in the human MPDU1 gene causes congenital disorder of glycosylation type If (CDG-If), J.Clin.Invest, 108 (2001) 1613-1619. [32] J. Helenius, D.T. Ng, C.L. Marolda, P. Walter, M.A. Valvano, M. Aebi, Translocation of lipid-linked oligosaccharides across the ER membrane requires Rft1 protein, Nature, 415 (2002) 447-450.

[33] M.A. Haeuptle, F.M. Pujol, C. Neupert, B. Winchester, A.J. Kastaniotis, M. Aebi, T. Hennet, Human RFT1 deficiency leads to a disorder of N-linked glycosylation, Am J Hum Genet, 82 (2008) 600606. 
[34] W. Vleugels, M.A. Haeuptle, B.G. Ng, J.C. Michalski, R. Battini, C. Dionisi-Vici, M.D. Ludman, J. Jaeken, F. Foulquier, H.H. Freeze, G. Matthijs, T. Hennet, RFT1 deficiency in three novel CDG patients, Hum Mutat, 30 (2009) 1428-1434.

[35] D.J. Kelleher, R. Gilmore, An evolving view of the eukaryotic oligosaccharyltransferase, Glycobiology, 16 (2006) 47R-62R.

[36] B.L. Schulz, C.U. Stirnimann, J.P. Grimshaw, M.S. Brozzo, F. Fritsch, E. Mohorko, G. Capitani, R. Glockshuber, M.G. Grutter, M. Aebi, Oxidoreductase activity of oligosaccharyltransferase subunits Ost3p and Ost6p defines site-specific glycosylation efficiency, Proc Natl Acad Sci U S A, 106 (2009) 11061-11066.

[37] F. Molinari, F. Foulquier, P.S. Tarpey, W. Morelle, S. Boissel, J. Teague, S. Edkins, P.A. Futreal, M.R. Stratton, G. Turner, G. Matthijs, J. Gecz, A. Munnich, L. Colleaux, Oligosaccharyltransferasesubunit mutations in nonsyndromic mental retardation, Am J Hum Genet, 82 (2008) 1150-1157. [38] M. Garshasbi, V. Hadavi, H. Habibi, K. Kahrizi, R. Kariminejad, F. Behjati, A. Tzschach, H. Najmabadi, H.H. Ropers, A.W. Kuss, A defect in the TUSC3 gene is associated with autosomal recessive mental retardation, Am J Hum Genet, 82 (2008) 1158-1164.

[39] C.M. de Praeter, G.J. Gerwig, E. Bause, L.K. Nuytinck, J.F.G. Vliegenthart, W. Breuer, J.P. Kamerling, M.F. Espeel, J.J.R. Martin, A.M. de Paepe, N. Wen Chun Chan, G.A. Dacremont, R.N. van Coster, A novel disorder caused by defective biosynthesis of $\mathrm{N}$-linked oligosaccharides due to glucosidase I deficiency, Am.J.Hum.Genet., 66 (2000) 1744-1756.

[40] Y. Yoshida, K. Tanaka, Lectin-like ERAD players in ER and cytosol, Biochim Biophys Acta, 1800 (2010) 172-180.

[41] M.A. Rafiq, A.W. Kuss, L. Puettmann, A. Noor, A. Ramiah, G. Ali, H. Hu, N.A. Kerio, Y. Xiang, M. Garshasbi, M.A. Khan, G.E. Ishak, R. Weksberg, R. Ullmann, A. Tzschach, K. Kahrizi, K. Mahmood, F. Naeem, M. Ayub, K.W. Moremen, J.B. Vincent, H.H. Ropers, M. Ansar, H. Najmabadi, Mutations in the alpha 1,2-mannosidase gene, MAN1B1, cause autosomal-recessive intellectual disability, Am J Hum Genet, 89 (2011) 176-182.

[42] J. Tan, J. Dunn, J. Jaeken, H. Schachter, Mutations in the MGAT2 gene controlling complex Nglycan synthesis cause carbohydrate-deficient glycoprotein syndrome type II, an autosomal recessive disease with defective brain development., Am.J.Hum.Genet., 59 (1996) 810-817.

[43] V. Cormier-Daire, J. Amiel, S. Vuillaumier-Barrot, J. Tan, G. Durand, A. Munnich, M. Le Merrer, N. Seta, Congenital disorders of glycosylation lla cause growth retardation, mental retardation, and facial dysmorphism, J Med Genet, 37 (2000) 875-877. 
[44] B. Hansske, C. Thiel, T. Lubke, M. Hasilik, S. Honing, V. Peters, P.H. Heidemann, G.F. Hoffmann, E.G. Berger, K. von Figura, C. Körner, Deficiency of UDP-galactose:N-acetylglucosamine $\beta-1,4-$ galactosyltransferase I causes the congenital disorder of glycosylation type IId, J.Clin.Invest., 109 (2002) 725-733.

[45] M. Guillard, E. Morava, J. de Ruijter, T. Roscioli, J. Penzien, L. van den Heuvel, M.A. Willemsen, A. de Brouwer, O.A. Bodamer, R.A. Wevers, D.J. Lefeber, B4GALT1-Congenital Disorders of Glycosylation Presents as a Non-Neurologic Glycosylation Disorder with Hepatointestinal Involvement, J Pediatr, (2011).

[46] X. Chen, A. Varki, Advances in the biology and chemistry of sialic acids, ACS Chem Biol, 5 (2010) 163-176.

[47] T. Hennet, D. Chui, J.C. Paulson, J.D. Marth, Immune regulation by the ST6Gal sialyltransferase, Proc.Natl.Acad.Sci.USA, 95 (1998) 4504-4509.

[48] J.J. Priatel, D. Chui, N. Hiraoka, C.J. Simmons, K.B. Richardson, D.M. Page, M. Fukuda, J.D. Marth, The ST3Gal-I sialyltransferase controls CD8 ${ }^{+} \mathrm{T}$ lymphocyte homeostasis by modulating O-glycan biosynthesis, Immunity, 12 (2000) 273-283.

[49] L.G. Ellies, D. Ditto, G.G. Levy, M. Wahrenbrock, D. Ginsburg, A. Varki, D.T. Le, J.D. Marth, Sialyltransferase ST3Gal-IV operates as a dominant modifier of hemostasis by concealing asialoglycoprotein receptor ligands, Proc Natl Acad Sci U S A, 99 (2002) 10042-10047.

[50] H. Hu, K. Eggers, W. Chen, M. Garshasbi, M.M. Motazacker, K. Wrogemann, K. Kahrizi, A. Tzschach, M. Hosseini, I. Bahman, T. Hucho, M. Muhlenhoff, R. Gerardy-Schahn, H. Najmabadi, H.H. Ropers, A.W. Kuss, ST3GAL3 Mutations Impair the Development of Higher Cognitive Functions, Am J Hum Genet, 89 (2011) 407-414.

[51] H. Kitagawa, J.C. Paulson, Differential expression of five sialyltransferase genes in human tissues, J Biol Chem, 269 (1994) 17872-17878.

[52] K.G. Ten Hagen, T.A. Fritz, L.A. Tabak, All in the family: the UDP-GalNAc:polypeptide Nacetylgalactosaminyltransferases, Glycobiology, 13 (2003) 1R-16R.

[53] O. Topaz, D.L. Shurman, R. Bergman, M. Indelman, P. Ratajczak, M. Mizrachi, Z. Khamaysi, D. Behar, D. Petronius, V. Friedman, I. Zelikovic, S. Raimer, A. Metzker, G. Richard, E. Sprecher, Mutations in GALNT3, encoding a protein involved in O-linked glycosylation, cause familial tumoral calcinosis, Nat Genet, 36 (2004) 579-581.

[54] I. Chefetz, E. Sprecher, Familial tumoral calcinosis and the role of O-glycosylation in the maintenance of phosphate homeostasis, Biochim Biophys Acta, 1792 (2009) 847-852. 
[55] K. Kato, C. Jeanneau, M.A. Tarp, A. Benet-Pages, B. Lorenz-Depiereux, E.P. Bennett, U. Mandel, T.M. Strom, H. Clausen, Polypeptide GalNAc-transferase T3 and familial tumoral calcinosis. Secretion of fibroblast growth factor 23 requires O-glycosylation, J Biol Chem, 281 (2006) 18370-18377.

[56] K. Guda, H. Moinova, J. He, O. Jamison, L. Ravi, L. Natale, J. Lutterbaugh, E. Lawrence, S. Lewis, J.K. Willson, J.B. Lowe, G.L. Wiesner, G. Parmigiani, J. Barnholtz-Sloan, D.W. Dawson, V.E. Velculescu, K.W. Kinzler, N. Papadopoulos, B. Vogelstein, J. Willis, T.A. Gerken, S.D. Markowitz, Inactivating germline and somatic mutations in polypeptide $\mathrm{N}$-acetylgalactosaminyltransferase 12 in human colon cancers, Proc Natl Acad Sci U S A, 106 (2009) 12921-12925.

[57] T. Ju, R.D. Cummings, A unique molecular chaperone Cosmc required for activity of the mammalian core 1 beta 3-galactosyltransferase, Proc.Natl.Acad.Sci.USA, 99 (2002) 16613-16618.

[58] T. Ju, R.D. Cummings, Protein glycosylation: chaperone mutation in Tn syndrome, Nature, 437 (2005) 1252.

[59] J.E. Hewitt, Abnormal glycosylation of dystroglycan in human genetic disease, Biochim Biophys Acta, 1792 (2009) 853-861.

[60] K. Kobayashi, Y. Nakahori, M. Miyake, K. Matsumura, E. Kondo-lida, Y. Nomura, M. Segawa, M. Yoshioka, K. Saito, M. Osawa, K. Hamano, Y. Sakakihara, I. Nonaka, Y. Nakagome, I. Kanazawa, Y. Nakamura, K. Tokunaga, T. Toda, An ancient retrotransposal insertion causes Fukuyama-type congenital muscular dystrophy, Nature, 394 (1998) 388-392.

[61] D. Beltran-Valero de Bernabe, S. Currier, A. Steinbrecher, J. Celli, E. van Beusekom, B. van der Zwaag, H. Kayserili, L. Merlini, D. Chitayat, W.B. Dobyns, B. Cormand, A.E. Lehesjoki, J. Cruces, T. Voit, C.A. Walsh, H. van Bokhoven, H.G. Brunner, Mutations in the O-mannosyltransferase gene POMT1 give rise to the severe neuronal migration disorder Walker-Warburg syndrome, Am J Hum Genet, 71 (2002) 1033-1043.

[62] J. van Reeuwijk, M. Janssen, C. van den Elzen, D. Beltran-Valero de Bernabe, P. Sabatelli, L. Merlini, M. Boon, H. Scheffer, M. Brockington, F. Muntoni, M. Huynen, A. Verrips, C. Walsh, P. Barth, H. Brunner, H. van Bokhoven, POMT2 mutations cause alpha-dystroglycan hypoglycosylation and Walker Warburg syndrome, J Med Genet, 42 (2005) 907-912.

[63] S.A. Moore, F. Saito, J. Chen, D.E. Michele, M.D. Henry, A. Messing, R.D. Cohn, S.E. Ross-Barta, S. Westra, R.A. Williamson, T. Hoshi, K.P. Campbell, Deletion of brain dystroglycan recapitulates aspects of congenital muscular dystrophy, Nature, 418 (2002) 422-425.

[64] A. Lunardi, F. Cremisi, L. Dente, Dystroglycan is required for proper retinal layering, Dev Biol, 290 (2006) 411-420. 
[65] F. Muntoni, M. Brockington, S. Torelli, S.C. Brown, Defective glycosylation in congenital muscular dystrophies, Curr Opin Neurol, 17 (2004) 205-209.

[66] K.B. Luther, R.S. Haltiwanger, Role of unusual O-glycans in intercellular signaling, Int J Biochem Cell Biol, 41 (2009) 1011-1024.

[67] P. Stanley, T. Okajima, Roles of glycosylation in Notch signaling, Curr Top Dev Biol, 92 (2010) 131164.

[68] D.B. Sparrow, G. Chapman, M.A. Wouters, N.V. Whittock, S. Ellard, D. Fatkin, P.D. Turnpenny, K. Kusumi, D. Sillence, S.L. Dunwoodie, Mutation of the lunatic fringe gene in humans causes spondylocostal dysostosis with a severe vertebral phenotype, Am J Hum Genet, 78 (2006) 28-37.

[69] S.A. Lesnik Oberstein, M. Kriek, S.J. White, M.E. Kalf, K. Szuhai, J.T. den Dunnen, M.H. Breuning, R.C. Hennekam, Peters Plus syndrome is caused by mutations in B3GALTL, a putative glycosyltransferase, Am J Hum Genet, 79 (2006) 562-566.

[70] L.J. Maillette de Buy Wenniger-Prick, R.C. Hennekam, The Peters' plus syndrome: a review, Ann Genet, 45 (2002) 97-103.

[71] E. Quentin, A. Gladen, L. Roden, H. Kresse, A genetic defect in the biosynthesis of dermatan sulfate proteoglycan: Galactosyltransferase I deficiency in fibroblasts from a patient with a progeroid syndrome, Proc.Natl.Acad.Sci.USA, 87 (1990) 1342-1346.

[72] T. Okajima, S. Fukumoto, K. Furukawa, T. Urano, Molecular basis for the progeroid variant of Ehlers-Danlos syndrome. Identification and characterization of two mutations in galactosyltransferase I gene, J.Biol.Chem., 274 (1999) 28841-28844.

[73] S. Baasanjav, L. Al-Gazali, T. Hashiguchi, S. Mizumoto, B. Fischer, D. Horn, D. Seelow, B.R. Ali, S.A. Aziz, R. Langer, A.A. Saleh, C. Becker, G. Nurnberg, V. Cantagrel, J.G. Gleeson, D. Gomez, J.B. Michel, S. Stricker, T.H. Lindner, P. Nurnberg, K. Sugahara, S. Mundlos, K. Hoffmann, Faulty initiation of proteoglycan synthesis causes cardiac and joint defects, Am J Hum Genet, 89 (2011) 15-27. [74] H. Knoblauch, M. Urban, S. Tinschert, Autosomal recessive versus autosomal dominant inheritance in Larsen syndrome: report of two affected sisters, Genet Couns, 10 (1999) 315-320. [75] C. Philippe, D.E. Porter, M.E. Emerton, D.E. Wells, A.H. Simpson, A.P. Monaco, Mutation screening of the EXT1 and EXT2 genes in patients with hereditary multiple exostoses, Am J Hum Genet, 61 (1997) 520-528. 
[76] C. McCormick, G. Duncan, K.T. Goutsos, F. Tufaro, The putative tumor suppressors EXT1 and EXT2 form a stable complex that accumulates in the Golgi apparatus and catalyzes the synthesis of heparan sulfate, Proc Natl Acad Sci U S A, 97 (2000) 668-673.

[77] Y. Li, K. Laue, S. Temtamy, M. Aglan, L.D. Kotan, G. Yigit, H. Canan, B. Pawlik, G. Nurnberg, E.L. Wakeling, O.W. Quarrell, I. Baessmann, M.B. Lanktree, M. Yilmaz, R.A. Hegele, K. Amr, K.W. May, P. Nurnberg, A.K. Topaloglu, M. Hammerschmidt, B. Wollnik, Temtamy preaxial brachydactyly syndrome is caused by loss-of-function mutations in chondroitin synthase 1, a potential target of BMP signaling, Am J Hum Genet, 87 (2010) 757-767.

[78] T. Yada, M. Gotoh, T. Sato, M. Shionyu, M. Go, H. Kaseyama, H. Iwasaki, N. Kikuchi, Y.D. Kwon, A. Togayachi, T. Kudo, H. Watanabe, H. Narimatsu, K. Kimata, Chondroitin sulfate synthase-2. Molecular cloning and characterization of a novel human glycosyltransferase homologous to chondroitin sulfate glucuronyltransferase, which has dual enzymatic activities, J Biol Chem, 278 (2003) 30235-30247.

[79] T. Yada, T. Sato, H. Kaseyama, M. Gotoh, H. Iwasaki, N. Kikuchi, Y.D. Kwon, A. Togayachi, T. Kudo, H. Watanabe, H. Narimatsu, K. Kimata, Chondroitin sulfate synthase-3. Molecular cloning and characterization, J Biol Chem, 278 (2003) 39711-39725.

[80] H. Thiele, M. Sakano, H. Kitagawa, K. Sugahara, A. Rajab, W. Hohne, H. Ritter, G. Leschik, P. Nurnberg, S. Mundlos, Loss of chondroitin 6-O-sulfotransferase-1 function results in severe human chondrodysplasia with progressive spinal involvement, Proc Natl Acad Sci U S A, 101 (2004) 1015510160.

[81] M. Dundar, T. Muller, Q. Zhang, J. Pan, B. Steinmann, J. Vodopiutz, R. Gruber, T. Sonoda, B. Krabichler, G. Utermann, J.U. Baenziger, L. Zhang, A.R. Janecke, Loss of dermatan-4-sulfotransferase 1 function results in adducted thumb-clubfoot syndrome, Am J Hum Genet, 85 (2009) 873-882.

[82] T.O. Akama, K. Nishida, J. Nakayama, H. Watanabe, K. Ozaki, T. Nakamura, A. Dota, S. Kawasaki, Y. Inoue, N. Maeda, S. Yamamoto, T. Fujiwara, E.J. Thonar, Y. Shimomura, S. Kinoshita, A. Tanigami, M.N. Fukuda, Macular corneal dystrophy type I and type II are caused by distinct mutations in a new sulphotransferase gene, Nat Genet, 26 (2000) 237-241.

[83] M.A. Simpson, H. Cross, C. Proukakis, D.A. Priestman, D.C. Neville, G. Reinkensmeier, H. Wang, M. Wiznitzer, K. Gurtz, A. Verganelaki, A. Pryde, M.A. Patton, R.A. Dwek, T.D. Butters, F.M. Platt, A.H. Crosby, Infantile-onset symptomatic epilepsy syndrome caused by a homozygous loss-of-function mutation of GM3 synthase, Nat Genet, 36 (2004) 1225-1229. 
[84] M. Bessler, P.J. Mason, P. Hillmen, T. Miyata, N. Yamada, J. Takeda, L. Luzzatto, T. Kinoshita, Paroxysmal nocturnal haemoglobinuria (PNH) is caused by somatic mutations in the PIG-A gene, Embo J, 13 (1994) 110-117.

[85] L. Luzzatto, M. Bessler, B. Rotoli, Somatic mutations in paroxysmal nocturnal hemoglobinuria: a blessing in disguise?, Cell, 88 (1997) 1-4.

[86] Y. Maeda, R. Watanabe, C.L. Harris, Y. Hong, K. Ohishi, K. Kinoshita, T. Kinoshita, PIG-M transfers the first mannose to glycosylphosphatidylinositol on the lumenal side of the ER, EMBO J, 20 (2001) 250-261.

[87] A.M. Almeida, Y. Murakami, D.M. Layton, P. Hillmen, G.S. Sellick, Y. Maeda, S. Richards, S. Patterson, I. Kotsianidis, L. Mollica, D.H. Crawford, A. Baker, M. Ferguson, I. Roberts, R. Houlston, T. Kinoshita, A. Karadimitris, Hypomorphic promoter mutation in PIGM causes inherited glycosylphosphatidylinositol deficiency, Nat Med, 12 (2006) 846-851.

[88] J.Y. Kang, Y. Hong, H. Ashida, N. Shishioh, Y. Murakami, Y.S. Morita, Y. Maeda, T. Kinoshita, PIG-V involved in transferring the second mannose in glycosylphosphatidylinositol, J Biol Chem, 280 (2005) 9489-9497.

[89] C.C. Mabry, A. Bautista, R.F. Kirk, L.D. Dubilier, H. Braunstein, J.A. Koepke, Familial hyperphosphatase with mental retardation, seizures, and neurologic deficits, J Pediatr, 77 (1970) 74 85.

[90] P.M. Krawitz, M.R. Schweiger, C. Rodelsperger, C. Marcelis, U. Kolsch, C. Meisel, F. Stephani, T. Kinoshita, Y. Murakami, S. Bauer, M. Isau, A. Fischer, A. Dahl, M. Kerick, J. Hecht, S. Kohler, M. Jager, J. Grunhagen, B.J. de Condor, S. Doelken, H.G. Brunner, P. Meinecke, E. Passarge, M.D. Thompson, D.E. Cole, D. Horn, T. Roscioli, S. Mundlos, P.N. Robinson, Identity-by-descent filtering of exome sequence data identifies PIGV mutations in hyperphosphatasia mental retardation syndrome, Nat Genet, 42 (2010) 827-829.

[91] D. Horn, P. Krawitz, A. Mannhardt, G.C. Korenke, P. Meinecke, Hyperphosphatasia-mental retardation syndrome due to PIGV mutations: expanded clinical spectrum, Am J Med Genet A, 155A (2011) 1917-1922.

[92] Y. Murakami, N. Kanzawa, K. Saito, P.M. Krawitz, S. Mundlos, P.N. Robinson, A. Karadimitris, Y. Maeda, T. Kinoshita, Mechanism for release of alkaline phosphatase caused by glycosylphosphatidylinositol deficiency in patients with hyperphosphatasia-mental retardation syndrome, J Biol Chem, (2012). 
[93] G. Maydan, I. Noyman, A. Har-Zahav, Z.B. Neriah, M. Pasmanik-Chor, A. Yeheskel, A. AlbinKaplanski, I. Maya, N. Magal, E. Birk, A.J. Simon, A. Halevy, G. Rechavi, M. Shohat, R. Straussberg, L. Basel-Vanagaite, Multiple congenital anomalies-hypotonia-seizures syndrome is caused by a mutation in PIGN, J Med Genet, 48 (2011) 383-389.

[94] T. Lubke, T. Marquardt, A. Etzioni, E. Hartmann, K. von Figura, C. Körner, Complementation cloning identifies CDG-IIc, a new type of congenital disorders of glycosylation, as a GDP-fucose transporter deficiency, Nat.Genet., 28 (2001) 73-76.

[95] T. Marquardt, K. Luhn, G. Srikrishna, H.H. Freeze, E. Harms, D. Vestweber, Correction of leukocyte adhesion deficiency type II with oral fucose, Blood, 94 (1999) 3976-3985.

[96] I. Martinez-Duncker, T. Dupre, V. Piller, F. Piller, J.J. Candelier, C. Trichet, G. Tchernia, R. Oriol, R. Mollicone, Genetic complementation reveals a novel human congenital disorder of glycosylation of type II, due to inactivation of the Golgi CMP-sialic acid transporter, Blood, 105 (2005) 2671-2676.

[97] M. Muraoka, M. Kawakita, N. Ishida, Molecular characterization of human UDP-glucuronic acid/UDP-N-acetylgalactosamine transporter, a novel nucleotide sugar transporter with dual substrate specificity, FEBS Lett, 495 (2001) 87-93.

[98] S. Hiraoka, T. Furuichi, G. Nishimura, S. Shibata, M. Yanagishita, D.L. Rimoin, A. Superti-Furga, P.G. Nikkels, M. Ogawa, K. Katsuyama, H. Toyoda, A. Kinoshita-Toyoda, N. Ishida, K. Isono, Y. Sanai, D.H. Cohn, H. Koseki, S. Ikegawa, Nucleotide-sugar transporter SLC35D1 is critical to chondroitin sulfate synthesis in cartilage and skeletal development in mouse and human, Nat Med, 13 (2007) 1363-1367.

[99] T. Furuichi, H. Kayserili, S. Hiraoka, G. Nishimura, H. Ohashi, Y. Alanay, J.C. Lerena, A.D. Aslanger, H. Koseki, D.H. Cohn, A. Superti-Furga, S. Unger, S. Ikegawa, Identification of loss-of-function mutations of SLC35D1 in patients with Schneckenbecken dysplasia, but not with other severe spondylodysplastic dysplasias group diseases, J Med Genet, 46 (2009) 562-568.

[100] T. Oka, D. Ungar, F.M. Hughson, M. Krieger, The COG and COPI complexes interact to control the abundance of GEARs, a subset of Golgi integral membrane proteins, Mol Biol Cell, 15 (2004) 2423-2435.

[101] D. Ungar, T. Oka, E.E. Brittle, E. Vasile, V.V. Lupashin, J.E. Chatterton, J.E. Heuser, M. Krieger, M.G. Waters, Characterization of a mammalian Golgi-localized protein complex, COG, that is required for normal Golgi morphology and function, J Cell Biol, 157 (2002) 405-415. 
[102] R. Zeevaert, F. Foulquier, B. Dimitrov, E. Reynders, R. Van Damme-Lombaerts, E. Simeonov, W. Annaert, G. Matthijs, J. Jaeken, Cerebrocostomandibular-like syndrome and a mutation in the conserved oligomeric Golgi complex, subunit 1, Hum Mol Genet, 18 (2009) 517-524.

[103] E. Reynders, F. Foulquier, E. Leao Teles, D. Quelhas, W. Morelle, C. Rabouille, W. Annaert, G. Matthijs, Golgi function and dysfunction in the first COG4-deficient CDG type II patient, Hum Mol Genet, 18 (2009) 3244-3256.

[104] P. Paesold Burda, C. Maag, H. Troxler, F. Foulquier, P. Kleinert, S. Schnabel, M. Baumgartner, T. Hennet, Deficiency in COG5 causes a mild form of congenital disorders of glycosylation, Hum Mol Genet, in press (2009).

[105] X. Wu, R.A. Steet, O. Bohorov, J. Bakker, J. Newell, M. Krieger, L. Spaapen, S. Kornfeld, H.H. Freeze, Mutation of the COG complex subunit gene COG7 causes a lethal congenital disorder, Nat Med, 10 (2004) 518-523.

[106] F. Foulquier, D. Ungar, E. Reynders, R. Zeevaert, P. Mills, M.T. Garcia-Silva, P. Briones, B. Winchester, W. Morelle, M. Krieger, W. Annaert, G. Matthijs, A new inborn error of glycosylation due to a Cog8 deficiency reveals a critical role for the Cog1-Cog8 interaction in COG complex formation, Hum Mol Genet, 16 (2007) 717-730.

[107] R. Zeevaert, F. Foulquier, J. Jaeken, G. Matthijs, Deficiencies in subunits of the Conserved Oligomeric Golgi (COG) complex define a novel group of Congenital Disorders of Glycosylation, Mol Genet Metab, 93 (2008) 15-21.

[108] M.N. Fukuda, T. Papayannopoulou, E.C. Gordon-Smith, H. Rochant, U. Testa, Defect in glycosylation of erythrocyte membrane proteins in congenital dyserythropoietic anaemia type II (HEMPAS), Br J Haematol, 56 (1984) 55-68.

[109] M.N. Fukuda, A. Dell, P. Scartezzini, Primary defect of congenital dyserythropoietic anemia type II. Failure in glycosylation of erythrocyte lactosaminoglycan proteins caused by lowered Nacetylglucosaminyltransferase II, J Biol Chem, 262 (1987) 7195-7206.

[110] M.N. Fukuda, K.A. Masri, A. Dell, L. Luzzatto, K.W. Moremen, Incomplete synthesis of N-glycans in congenital dyserythropoietic anemia type II caused by a defect in the gene encoding $\alpha$ mannosidase II, Proc.Natl.Acad.Sci.USA, 87 (1990) 7443-7447.

[111] K. Schwarz, A. Iolascon, F. Verissimo, N.S. Trede, W. Horsley, W. Chen, B.H. Paw, K.P. Hopfner, K. Holzmann, R. Russo, M.R. Esposito, D. Spano, L. De Falco, K. Heinrich, B. Joggerst, M.T. Rojewski, S. Perrotta, J. Denecke, U. Pannicke, J. Delaunay, R. Pepperkok, H. Heimpel, Mutations affecting the 
secretory COPII coat component SEC23B cause congenital dyserythropoietic anemia type II, Nat Genet, 41 (2009) 936-940.

[112] E. Morava, S. Wopereis, P. Coucke, G. Gillessen-Kaesbach, T. Voit, J. Smeitink, R. Wevers, S. Grunewald, Defective protein glycosylation in patients with cutis laxa syndrome, Eur J Hum Genet, 13 (2005) 414-421.

[113] U. Kornak, E. Reynders, A. Dimopoulou, J. van Reeuwijk, B. Fischer, A. Rajab, B. Budde, P. Nurnberg, F. Foulquier, D. Lefeber, Z. Urban, S. Gruenewald, W. Annaert, H.G. Brunner, H. van Bokhoven, R. Wevers, E. Morava, G. Matthijs, L. Van Maldergem, S. Mundlos, Impaired glycosylation and cutis laxa caused by mutations in the vesicular H+-ATPase subunit ATP6V0A2, Nat Genet, 40 (2008) 32-34. 


\section{Figure legends}

Figure 1. Biosynthesis of the activated sugars UDP-Gal, UDP-Glc, Dol-P-Glc, UDP-GIcNAc, GDP-Man, Dol-P-Man and CMP-Sia. Sugars are represented graphically using the symbols recommended by the Consortium for Functional Glycomics (see http://glycomics.scripps.edu/CFGnomenclature.pdf). The gene defects known to impair nucleotide-sugar and Dol-P-sugar biosynthesis are marked in red beside the involved reactions.

Figure 2. Lipid-linked oligosaccharide biosynthesis. The sequential assembly of the lipid-linked oligosaccharide Dol-PP-GICNAc $2 \mathrm{Man}_{9} \mathrm{Glc}_{3}$ at the ER membrane is represented with the known gene defects marked in red. The glycosyltransferases not yet associated with a type of CDG are marked in blue. The symbol OST is used to represent the complex including the subunits STT3A/B, RPN1, RPN2, DDOST, DAD1 and OST4.

Figure 3. N-glycan structures. The high-mannose form found in the ER and a typical biantennary form of N-glycans built in the Golgi apparatus are represented schematically featuring the enzymes known to be associated with CDG.

Figure 4. O-glycan structures. Typical O-GalNAc, O-Man and O-Fuc glycans are shown together with the glycosyltransferases and putative glycosyltransferases involved in some types of CDG.

Figure 5. Glycosaminogycan structures. Schematic representation of heparan, chondroitin and dermatan sulfate chains including the glycosyltransferases involved in CDG. The sulfotransferases CHST3 and CHST14, which modify chondroitin and dermatan are not shown on this figure.

Figure 6. Glycolipid structures. The ganglioside GM1 is shown as example with indication of the sialyltransferase reaction mediated by the ST3GAL5 enzyme. The structure of the GPI-anchor is represented schematically together with the enzymes defective in four types of CDG. EtN, ethanolamine. 


\begin{tabular}{|c|c|c|c|}
\hline Gene & Gene locus MIM \# & Function & Disease \\
\hline \multicolumn{4}{|c|}{ Nucleotide-sugar biosynthesis } \\
\hline PMM2 & 601785 & $\begin{array}{l}\text { Phosphomannomutase } \\
\text { (Man-6-P } \rightarrow \text { Man-1-P) }\end{array}$ & PMM2-CDG (CDG-la) \\
\hline$M P I$ & 154550 & $\begin{array}{l}\text { Phosphomannose isomerase } \\
\text { (Fru-6-P } \rightarrow \text { Man-6-P) }\end{array}$ & MPI-CDG (CDG-Ib) \\
\hline GFPT1 & 138292 & $\begin{array}{l}\text { Glutamine:fructose-6-phosphate } \\
\text { amidotransferase }\end{array}$ & $\begin{array}{l}\text { Congenital myasthenic } \\
\text { syndrome }\end{array}$ \\
\hline GNE & 603824 & $\begin{array}{l}\text { UDP-N-acetylglucosamine 2- } \\
\text { epimerase }\end{array}$ & $\begin{array}{l}\text { Hereditary inclusion body } \\
\text { myopathy }\end{array}$ \\
\hline GALK & 604313 & Gal kinase & Galactosemia \\
\hline GALT & 606999 & Gal-1-P uridylyltransferase & Galactosemia \\
\hline GALE & 606953 & UDP-Gal 4-epimerase & Galactosemia \\
\hline \multicolumn{4}{|c|}{ Dolichol biosynthesis } \\
\hline DHDDS & 608172 & Cis-prenol synthase & Retinitis pigmentosa \\
\hline SRD5A3 & 611715 & Polyprenol reductase & SRD5A3-CDG (CDG-Iq) \\
\hline TMEM15 & 610746 & Dol kinase & TMEM15-CDG (CDG-Im) \\
\hline \multicolumn{4}{|c|}{ Lipid-linked oligosaccharide biosynthesis } \\
\hline DPAGT1 & 191350 & GlcNAc-1-P transferase & DPAGT1-CDG (CDG-lj) \\
\hline ALG1 & 605907 & $\beta 1-4$ Man-transferase & ALG1-CDG (CDG-Ik) \\
\hline ALG2 & 607905 & $\alpha 1-3 / 6$ Man-transferase & ALG2-CDG (CDG-li) \\
\hline ALG11 & 613666 & $\alpha 1-2$ Man-transferase & ALG11-CDG (CDG-Ip) \\
\hline RFT1 & 611908 & LLO translocation & RFT1-CDG (CDG-In) \\
\hline MPDU1 & 604041 & Dol-P-Man/Glc availability (?) & MPDU1-CDG (CDG-If) \\
\hline$D P M 1$ & 603503 & Dol-P-Man synthase & DPM1-CDG (CDG-le) \\
\hline
\end{tabular}




\begin{tabular}{|c|c|c|c|}
\hline$D P M 3$ & 605951 & Dol-P-Man synthase & DPM3-CDG (CDG-Io) \\
\hline ALG3 & 608750 & 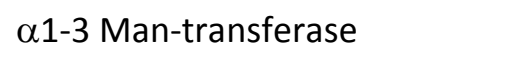 & ALG3-CDG (CDG-Id) \\
\hline ALG9 & 606941 & $\alpha 1-2$ Man-transferase & ALG9-CDG (CDG-IL) \\
\hline ALG12 & 607144 & a1-6 Man-transferase & ALG12-CDG (CDG-Ig) \\
\hline ALG6 & 604566 & $\alpha 1-3$ Glc-transferase & ALG6-CDG (CDG-IC) \\
\hline ALG8 & 608103 & $\alpha 1-3$ Glc-transferase & ALG8-CDG (CDG-Ih) \\
\hline \multicolumn{4}{|c|}{ N-glycosylation } \\
\hline TUSC3/N33 & 601385 & Oligosaccharyltransferase & $\begin{array}{l}\text { Autosomal recessive mental } \\
\text { retardation }\end{array}$ \\
\hline IAP/MAGT1 & 300715 & Oligosaccharyltransferase & X-linked mental retardation \\
\hline GCS1 & 601336 & $\alpha 1-2$ glucosidase & GCS1-CDG (CDG-IIb) \\
\hline MAN1B1 & 604346 & ER $\alpha 1-2$ mannosidase-I & $\begin{array}{l}\text { Autosomal recessive mental } \\
\text { retardation }\end{array}$ \\
\hline MGAT2 & 602616 & $\beta 1-2$ GlcNAc-transferase & MGAT2-CDG (CDG-Ila) \\
\hline B4GALT1 & 137060 & $\beta 1-4$ Gal-transferase & B4GALT1-CDG (CDG-IId) \\
\hline ST3GAL3 & 606494 & $\alpha 2-3$ Sia-transferase & $\begin{array}{l}\text { Autosomal recessive mental } \\
\text { retardation }\end{array}$ \\
\hline \multicolumn{4}{|c|}{ O-GalNAc glycosylation } \\
\hline GALNT3 & 601756 & polypeptide GalNAc-transferase & Familial tumoral calcinosis \\
\hline GALNT12 & 610290 & polypeptide GalNAc-transferase & $\begin{array}{l}\text { Colorectal cancer } \\
\text { susceptibility }\end{array}$ \\
\hline COSMC & 300611 & $\begin{array}{l}\text { Core } 1 \beta 1-3 \text { Gal-transferase } \\
\text { chaperone }\end{array}$ & Tn syndrome \\
\hline \multicolumn{4}{|c|}{ O-Man glycosylation } \\
\hline POMT1 & 607423 & Protein O-Man-transferase & Walker-Warburg syndrome \\
\hline POMT2 & 607439 & Protein O-Man-transferase & Walker-Warburg syndrome \\
\hline
\end{tabular}




\begin{tabular}{|c|c|c|c|}
\hline POMGNT1 & 606822 & $\beta 1-2$ GlcNAc-transferase & Muscle-Eye-Brain disease \\
\hline$L A R G E$ & 603590 & $\begin{array}{l}\beta 1-3 \text { GlcA-transferase/ } \alpha 1-3 \mathrm{Xyl}- \\
\text { transferase }\end{array}$ & $\begin{array}{l}\text { MDC1D, limb-girdle muscular } \\
\text { dystrophy }\end{array}$ \\
\hline FKTN & 607440 & unknown & $\begin{array}{l}\text { Fukuyama congenital } \\
\text { muscular dystrophy }\end{array}$ \\
\hline FKRP & 606596 & unknown & $\begin{array}{l}\text { MDC1C, limb-girdle muscular } \\
\text { dystrophy }\end{array}$ \\
\hline \multicolumn{4}{|c|}{ O-Fuc glycosylation } \\
\hline LFNG & 602576 & $\beta 1-3$ GlcNAc-transferase & Spondylocostal dysostosis \\
\hline B3GALTL & 610308 & $\beta 1-3$ Glc-transferase & Peters-Plus syndrome \\
\hline \multicolumn{4}{|c|}{ Glycosaminoglycan glycosylation } \\
\hline XGPT1 & 604327 & Xyl $\beta 1-4$ Gal-transferase & $\begin{array}{l}\text { Ehlers-Danlos syndrome } \\
\text { (progeroid type) }\end{array}$ \\
\hline B3GAT3 & 606374 & $\beta 1-3$ GlcA-transferase & $\begin{array}{l}\text { Multiple joint dislocations, } \\
\text { short stature, craniofacial } \\
\text { dysmorphism, and congenital } \\
\text { heart defects }\end{array}$ \\
\hline EXT1 & 608177 & Heparan sulfate polymerase & Multiple exostoses \\
\hline EXT2 & 608210 & Heparan sulfate polymerase & Multiple exostoses \\
\hline CHSY1 & 608183 & Chondroitin synthase 1 & $\begin{array}{l}\text { Temtamy preaxial } \\
\text { brachydactyly syndrome }\end{array}$ \\
\hline CHST3 & 603799 & Chondroitin 6-sulfotransferase & $\begin{array}{l}\text { Spondyloepiphyseal dysplasia } \\
\text { with joint dislocations }\end{array}$ \\
\hline CHST14 & 608429 & Dermatan-4-sulfotransferase-1 & $\begin{array}{l}\text { Ehlers-Danlos syndrome } \\
\text { (musculocontractural type) }\end{array}$ \\
\hline CHST6 & 605294 & Keratan GIcNAc-6-O-sulfotransferase & Macular corneal dystrophy \\
\hline \multicolumn{4}{|c|}{ Glycolipid glycosylation } \\
\hline ST3GAL5 & 604402 & a2-3 Sia-transferase (GM3 synthase) & $\begin{array}{l}\text { Amish infantile epilepsy } \\
\text { syndrome }\end{array}$ \\
\hline PIGA & 311770 & GPI GIcNAc-transferase & Paroxysmal nocturnal \\
\hline
\end{tabular}




\begin{tabular}{|c|c|c|c|}
\hline & & & hemoglobinuria \\
\hline PIGM & 610273 & GPI Man-transferase & GPI deficiency \\
\hline PIGV & 610274 & GPI Man-transferase & Mabry syndrome \\
\hline PIGN & 606097 & GPI ethanolamine-P transferase-1 & $\begin{array}{l}\text { Multiple congenital } \\
\text { anomalies-hypotonia- } \\
\text { seizures syndrome }\end{array}$ \\
\hline \multicolumn{4}{|c|}{ Nucleotide-sugar transport } \\
\hline SLC35C1 & 605881 & GDP-Fuc transport & SLC35C1-CDG (CDG-IIC) \\
\hline SLC35A1 & 605634 & CMP-Sia transport & SLC35A1-CDG (CDG-IIf) \\
\hline SLC35D1 & 610804 & UDP-GIcA/GalNAc transport & Schneckenbecken dysplasia \\
\hline \multicolumn{4}{|c|}{ Vesicular transport } \\
\hline COG1 & 606973 & $\begin{array}{l}\text { Conserved oligomeric Golgi (COG) } \\
\text { complex }\end{array}$ & COG1-CDG (CDG-IIg) \\
\hline COG4 & 606976 & $\begin{array}{l}\text { Conserved oligomeric Golgi (COG) } \\
\text { complex }\end{array}$ & COG4-CDG (CDG-IIj) \\
\hline COG5 & 606821 & $\begin{array}{l}\text { Conserved oligomeric Golgi (COG) } \\
\text { complex }\end{array}$ & COG5-CDG (CDG-IIi) \\
\hline COG7 & 606978 & $\begin{array}{l}\text { Conserved oligomeric Golgi (COG) } \\
\text { complex }\end{array}$ & COG7-CDG (CDG-Ile) \\
\hline COG8 & 606979 & $\begin{array}{l}\text { Conserved oligomeric Golgi (COG) } \\
\text { complex }\end{array}$ & COG8-CDG (CDG-IIh) \\
\hline SEC23B & 610512 & COPII subunit (ER to Golgi transport) & $\begin{array}{l}\text { Dyserythropoietic congenital } \\
\text { anemia type II }\end{array}$ \\
\hline ATPVOA2 & 611716 & $\mathrm{H}+$ /ATPase, $\mathrm{pH}$ regulation in Golgi & $\begin{array}{l}\text { Autosomal recessive cutis } \\
\text { laxa }\end{array}$ \\
\hline
\end{tabular}


Figure 1

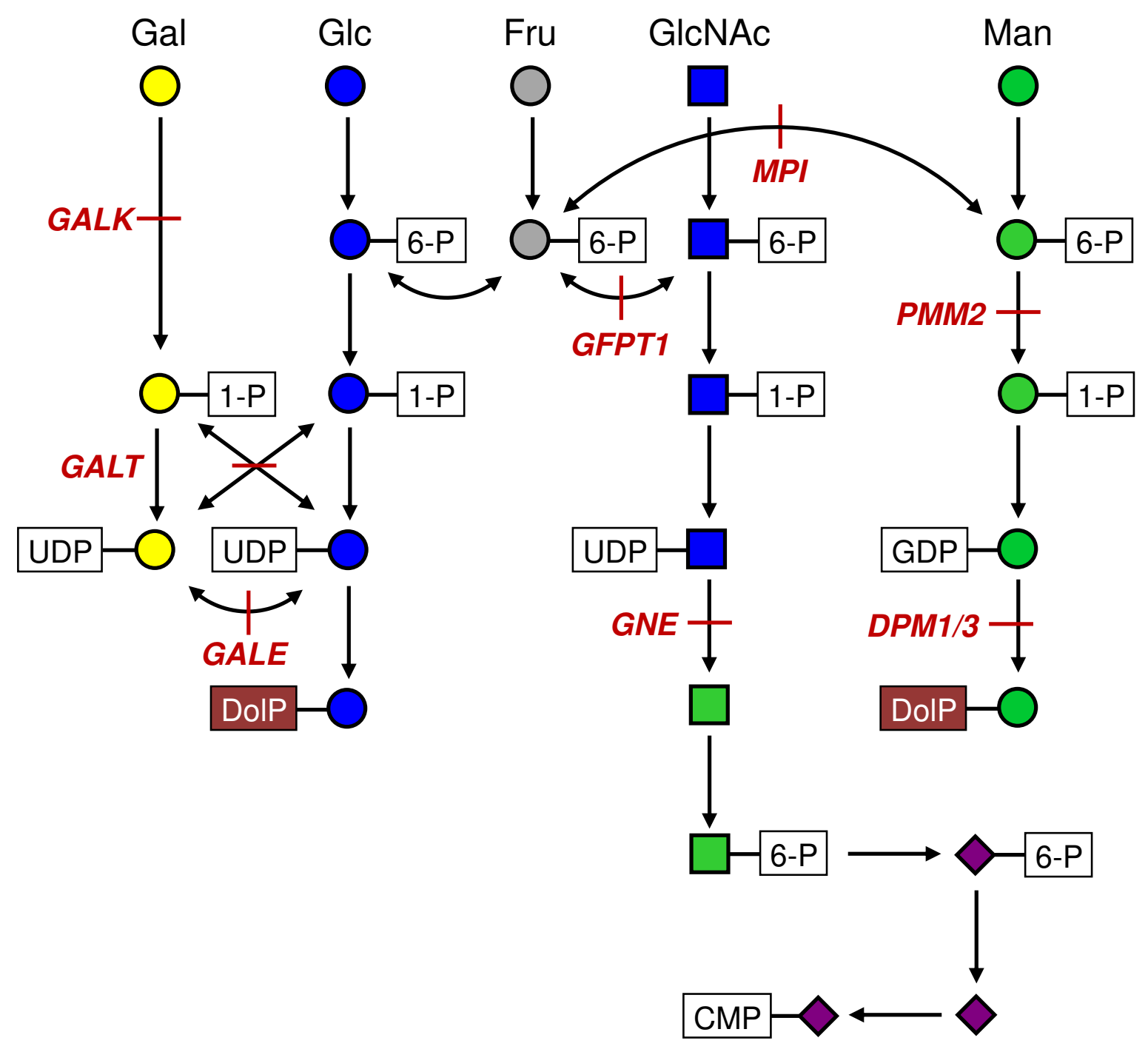


Figure 2

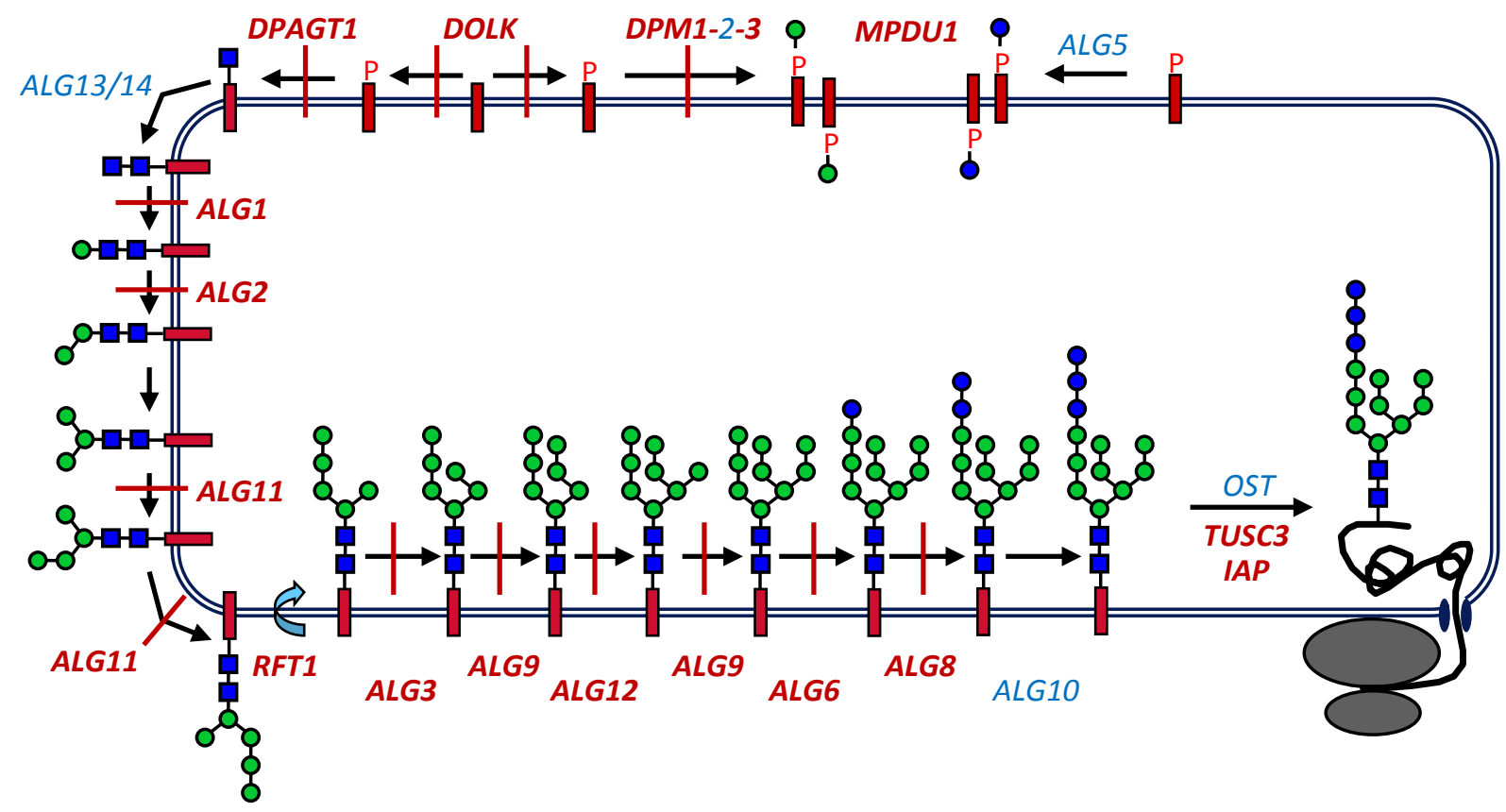


Figure 3

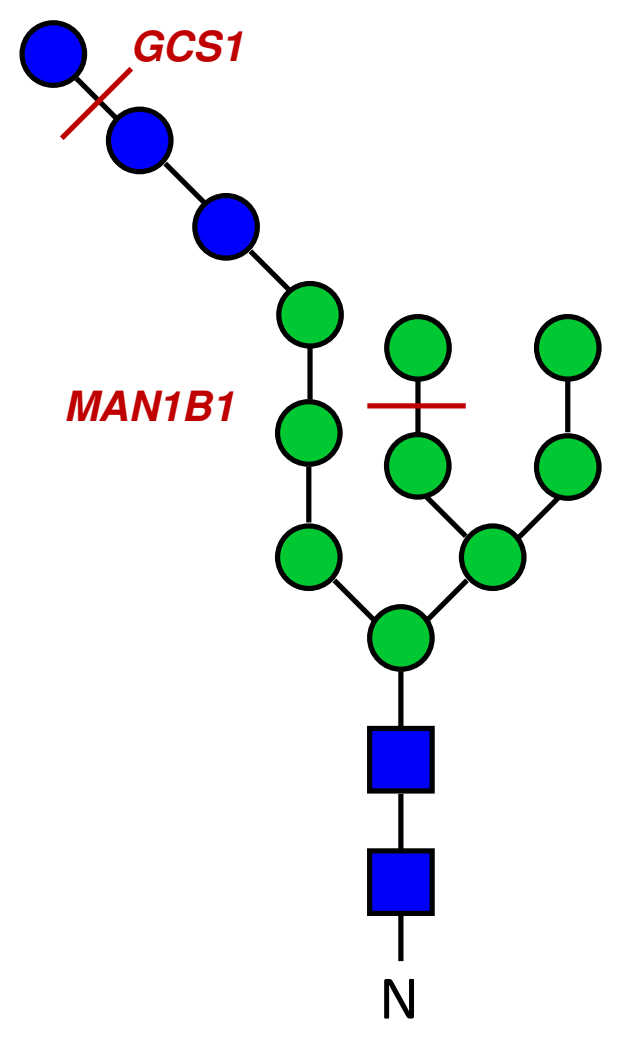

$\mathrm{N}$-glycan (ER)

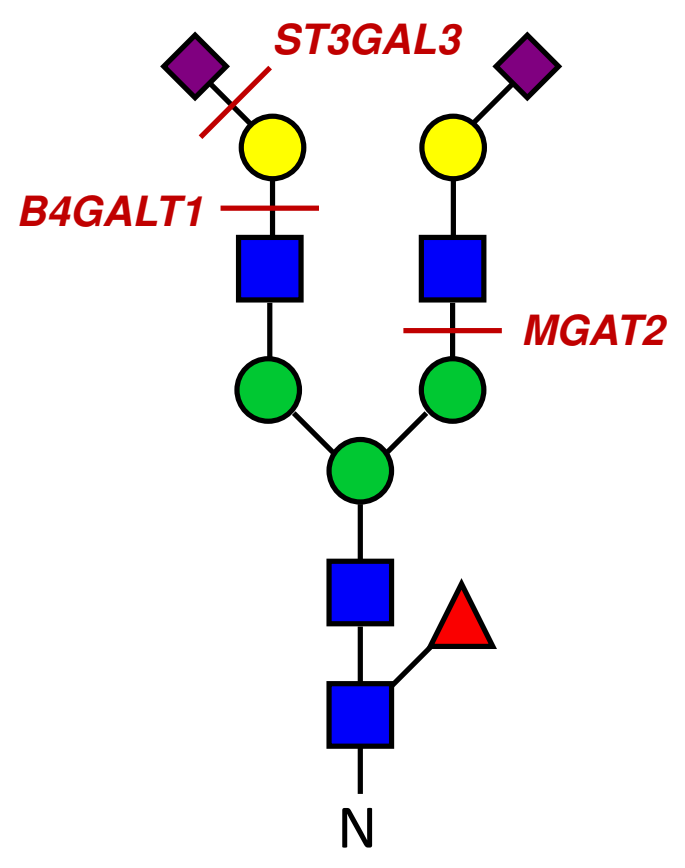

N-glycan (Golgi) 
Figure 4

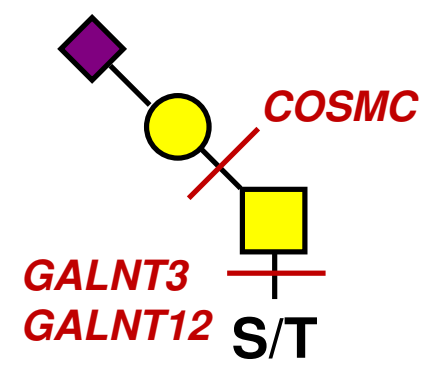

O-GalNAc

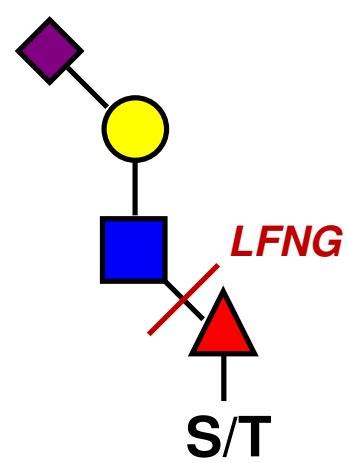

EGF O-Fuc

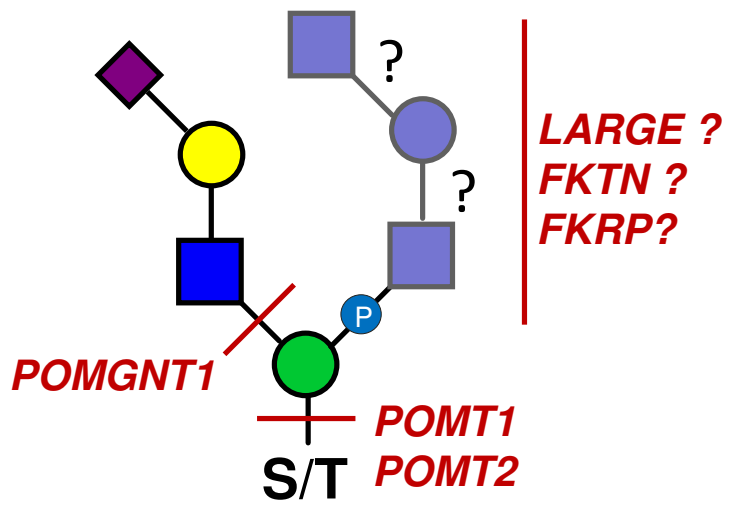

O-Man

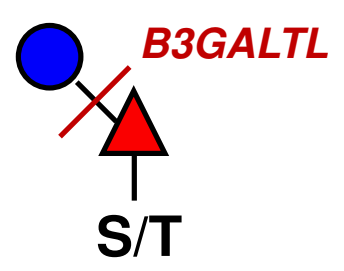

TSP O-Fuc 
Figure 5

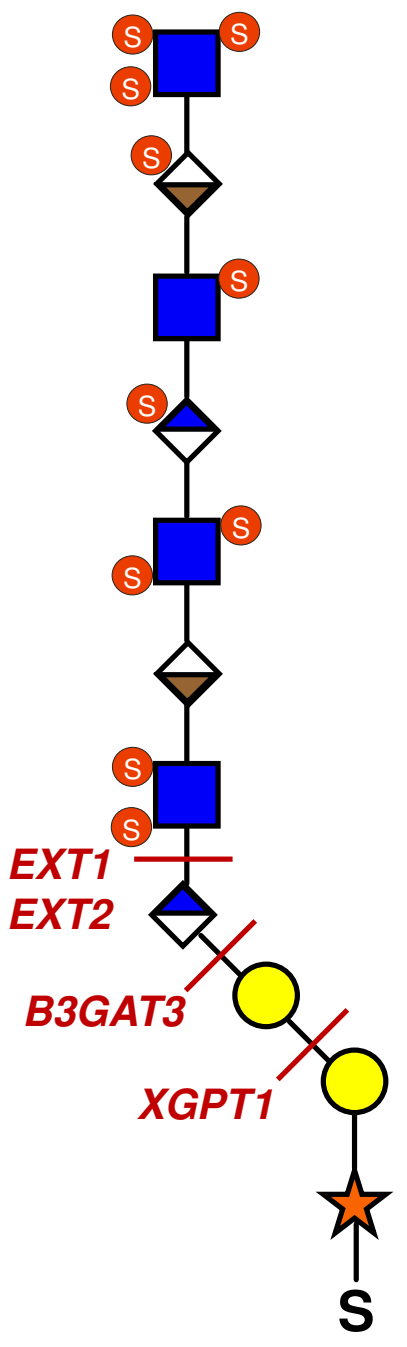

Heparan sulfate

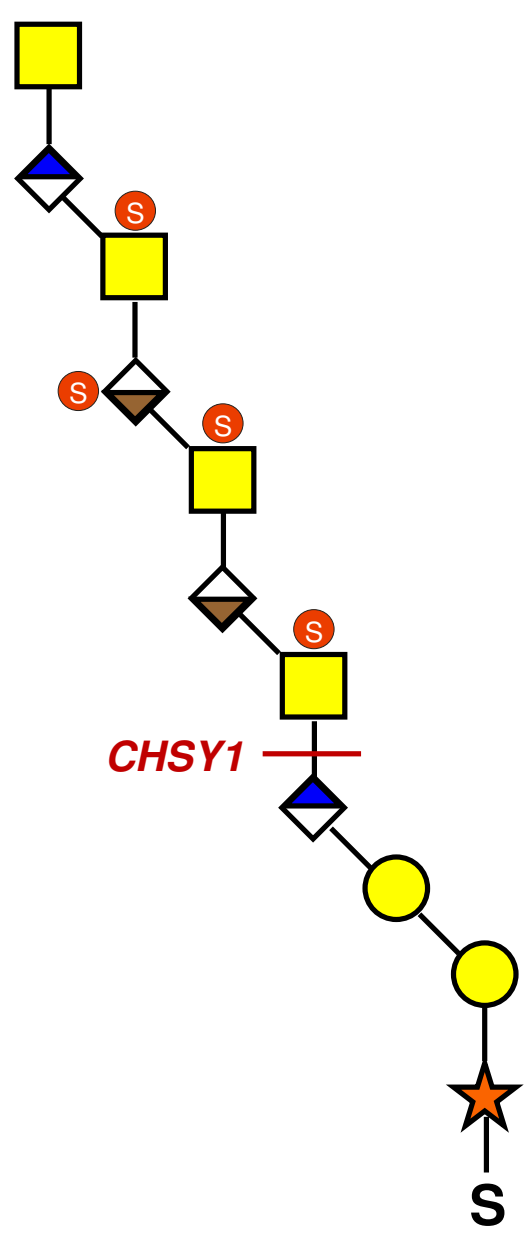

Chondroitin sulfate Dermatan sulfate 
Figure 6

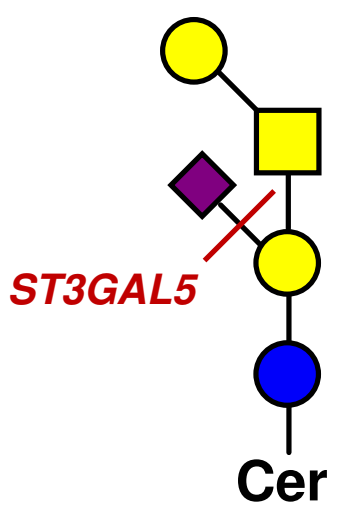

Ganglioside

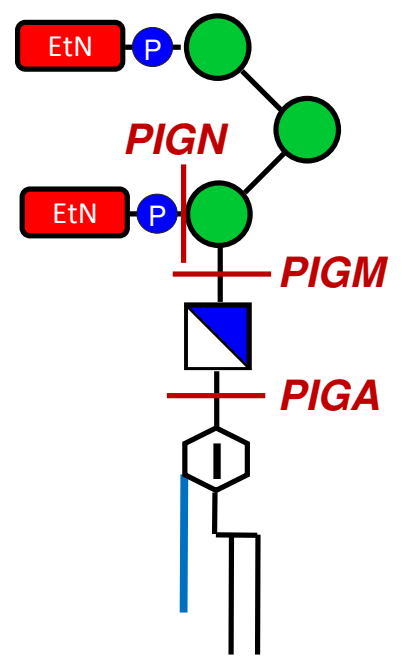

GPI anchor 